\title{
Hvordan gjøre scenekunst med teatervitenskap
}

\author{
André Eiermann
}

\begin{abstract}
This article is based on a lecture presented on the $25^{\text {th }}$ of May 2018 at the conference Teatervitenskap - bistoriografi, teori og praksis in Bergen. The objective of the conference was to defend the section of Theatre Studies at the University of Bergen against cuts. The lecture's corresponding objective was to exemplify how theatre studies, besides consisting in research on performing arts, also is productively effective in creative processes of performing arts - respectively in this field's artistic research. In relation to the three focal points of the conference: historiography, theory, and practice, the lecture referred to three examples: Mette Ingvartsen's performance 69 positions from 2014, Iggy Malmborg's performance $b$ o $n$ e r, also from 2014, and the author's own work as a theatre scholar with a background in applied theatre studies - particularly his collaboration as a dramaturge with Heine Avdal and Yukiko Shinozaki / fieldworks in their productions distant voices (2014), carry on (2015) and unannounced (2017). The article presents these examples based on a discussion on, firstly, the arguments that were used to defend theatre studies in the conference's context and, secondly, the relation between research and artistic research in Norway and the debate about it.
\end{abstract}

Keywords: Applied theatre studies, artistic research, performative force, the voice as object, bodiless organs.

\section{Om forfatteren}

André Eiermann er professor i teater ved Universitetet i Agder. Tidligere var han bl.a. vikarierende professor i teaterteori og -historie ved Universität der Künste Berlin (2015-2016), vikarierende professor i teatervitenskap ved Goethe-Universität Frankfurt am Main (2010-2011), og postdoktor ved Institutt for Anvendt Teatervitenskap ved Justus-Liebig-Universität Giessen (2009-2010 \& 2011-2012). I tillegg er han aktiv som scenekunstner siden 2001 og har samarbeidet som dramaturg med ulike andre kunstnere siden 2013 i både den norske og den internasjonale konteksten. Hans doktorgradsavhandling Postspektakuläres Theater ble publisert i 2009.

Teatervitenskapelige studier 2021 (C) André Eiermann

Nummerredaktører: Ellen K. Gjervan, Siren Leirvåg, Ragnhild Gjefsen, Ulla K. H. Kallenbach Ansvarlig redaktør: Ulla Kathrin Helena Kallenbach - ulla.kallenbach@,uib.no

Publisert av Teatervitenskap, Institutt for lingvistiske, litterære og estetiske studier, Universitetet i Bergen Bergen Open Access Publishing - https://boap.uib.no/index.php/tvs

ISSN: 2535-7662 
EIERMANN

andre.eiermann@uia.no 


\section{Hvordan gjøre scenekunst med teatervitenskap}

Denne artikkelen baserer seg på et foredrag av samme navn, presentert 25. mai 2018 på konferansen Teatervitenskap - historiografi, teori og praksis i Bergen. Den gang dreide det seg som kjent om å bevare teatervitenskap. Nærmere bestemt dreide konferansen seg om å forsvare faget mot en nedskjæringstrussel - en trussel med en egen historie: Allerede i 2012 hadde denne trusselen rammet faget hardt, da teatervitenskap ved Universitetet i Oslo hadde blitt offer for den. Og så, seks år senere, hadde den blitt konkret igjen da det var en overhengende fare for teatervitenskap ved Universitetet i Bergen. Foredragets hensikt var i denne sammenhengen å eksemplifisere hvordan teatervitenskap, ved siden av å bestå av forskning på scenekunst, også virker som produktivt element i skapende, scenekunstneriske prosesser. Tesen var altså at teatervitenskap har del i scenekunstnerisk utviklingsarbeid - både gjennom medvirkning av teatervitere i scenekunstneriske prosesser og som vitenskapelig diskurs som scenekunstnere refererer og forholder seg til i deres arbeider.

I henhold til konferansens tre tematiske fokusområder - historiografi, teori og praksis - gikk foredraget inn på tre eksempler: Mette Ingvartsens arbeid 69 positions (2014) i forbindelse med historiografifokuset, Iggy Malmborgs arbeid $b$ o n e $r$ (2014) i forbindelse med teorifokuset, og $\mathrm{i}$ forbindelse med praksisfokuset, mitt eget scenekunstnerisk arbeid som teaterviter med utdanning fra Institut für Angewandte Theaterwisssenschaft i Giessen (Tyskland), og særlig mitt samarbeid som dramaturg med Heine Avdal og Yukiko Shinozaki / fieldworks i deres produksjoner distant voices (2014), carry on (2015) og unannounced (2017).

Den foreliggende artikkelen drøfter disse eksemplene langs den lett forandrete rekkefølgen praksis - historiografi - teori. I tillegg begynner artikkelen med en oversikt over og diskusjon om to diskursive kontekster som vedkommer tematikken, før eksemplene følger. For det første er det de argumentasjonsmåtene og -strategiene som, i sammenheng med konferansen i Bergen og utover det, ble brukt for å forsvare teatervitenskap. For det andre, delvis i forbindelse med førstnevnte, er det den norske debatten om forholdet mellom forskning og kunstnerisk utviklingsarbeid. Særlig med henblikk på utviklingen som har skjedd i tidsrommet som ligger mellom foredraget i Bergen og artikkelens ferdigstilling synes diskusjonen om disse to kontekstene relevant. Artikkelen utvider dermed foredragets opprinnelige innhold med et tilbakeblikk på disse kontekstene.

\section{Hvorfor bevare teatervitenskap? Og hvordan besvare det?}

I forkant av konferansen i Bergen i 2018 fantes det to hovedstrategier å argumentere på for å forsvare faget, eller for å svare på spørsmålet hvorfor teatervitenskap må bevares: Den første strategien bestod i å påpeke det «nasjonale ansvaret» for teatervitenskap, som Universitetet i Bergen hadde påtatt seg i sammenheng med nedleggelsen av faget i Oslo. Særlig ble det betont at Universitetet i Bergen rommet det eneste gjenværende teatervitenskapelige fagmiljøet i Norge - i det minste det eneste med en klassisk fagprofil. Den andre strategien bestod i å framheve hvor 
relevant teatervitenskap er for praksisfeltet. For eksempel påpekte Knut Ove Arntzen, hvor avgjørende et utdanningstilbud som «bidrar til en teoretisk forståelse for regi- og skuespillerkunst» ved å ikke bekrefte «stereotypiske oppfatninger av hva teater var», men «heller vise det i sin fulle historiske bredde og si noe om hva det også kunne være» ${ }^{1}$, er for utviklingen av nyskapende praksisformer.

Denne andre strategien er, fra mitt perspektiv, både mer plausibel og mer effektiv med hensyn til fagets forsvar enn den første (selv om det å bruke «nasjonalt-ansvan»-argumentet var forståelig i lys av hvordan situasjonen hadde utviklet seg). Jeg synes også at den tilhørende argumentasjonen til strategi nummer to generelt er mer relevant enn tanken om at én institusjon alene skal kunne sikre teatervitenskapens eksistens. ${ }^{2}$ Én årsak til det, er at den andre strategien tilsvarer mitt eget syn på forholdet mellom teatervitenskap og scenekunst, som er preget av min utdanning i anvendt teatervitenskap, den tilsvarende forbindelsen mellom teori og praksis, og mitt arbeid i både akademiske og kunstneriske sammenhenger. En annen årsak er at jeg særlig deler Arntzens oppfatning om at et kritisk blikk på stereotypiske teateroppfatninger og spørsmålet om hva teater kan være ${ }^{3}$ er av sentral betydning for teatervitenskapens relevans. Det å sette spørsmålstegn ved stereotypiske teateroppfatninger er, etter mitt skjønn, generelt én av teatervitenskapens hovedoppgaver. Særlig aktuell er denne oppgaven i lys av koronakrisen. For denne krisen har, i det minste i første omgang, framkalt reaksjoner som hovedsakelig består i å påpeke teaterets angivelig vesentlige kjennetegn. Ganske sjelden er derimot refleksjoner over spørsmålet om disse kjennetegnene ikke bare er det som en stereotypisk teateroppfatning vil anse som vesentlig. ${ }^{4}$ Men først og fremst vurderer jeg den nevnte andre strategien som mye mer relevant enn den første fordi den ikke bare adresserer humanioramiljøet. Eller med andre ord, og konkret i henhold til den ovenfor siterte artikkelen av Arntzen: Akkurat fordi denne artikkelen adresserer humanioramiljøet ved å kritisere dets «elfenbenstårn-tenkning» og dets måte «å insistere på akademisk distanse til feltet som studeres som om forskningen er tilstrekkelig i seg selv», var og er dens argumentasjon så relevant. ${ }^{5}$

Særlig ved at Arntzen påpeker at «[e]n forskningsfront i skjæringspunktet mellom teori og praksis burde være det ideelle» ${ }^{6}$ utfoldes denne relevansen. Ved å argumentere sånn dannes det nemlig også referansepunkter for både akademiske, teaterfaglige miljøer utenfor humaniorafakulteter og scenekunstneriske miljøer utenfor universitets- og høgskolesektoren. Argumentasjonsmåten som

\footnotetext{
${ }^{1}$ Arntzen, Knut Ove. «Mye står på spill for teatervitenskaps-faget i Bergen.» Bergens Tidende. 30.11.2017.

2 Jf. Eiermann, André. «Behovet for dynamikk». Norsk Shakespeare- og Teatertidsskrift, nr. 2 (2018): 27-28.

${ }^{3}$ Jf. Eiermann, André, i intervju med Frøysnes, Valborg. «Hva kan teater være?». Norsk Shakespeare- og Teatertidsskrift, nr. 2 (2013): 6-10.

${ }^{4}$ Denne stereotypiske teateroppfatningen består i dag, etter utviklingen av postdramatiske teaterformer, ikke lenger $\mathrm{i}$ å anse teater «som en funksjon av litteraturen i scenisk representasjon» (Arntzen, «Mye står på spill for teatervitenskaps-faget i Bergen»), slik som ved grunnleggelsen av teatervitenskap i Bergen for mer enn 50 år siden. De nåværende stereotypiene er heller preget av å anse en felles tilstedeværelse av aktører og tilskuere og deres umiddelbare gjensidige sansing som teaterets vesentlige kjennemerker. Reaksjonene på koronakrisen synliggjør disse stereotypiene på en veldig tydelig måte - og viser hvor viktig det er å minne om at både et mangfold av scenekunstneriske utviklinger og tilsvarende teoretiske diskurser har for lengst satt spørsmålstegn ved disse stereotypiene (jf. Eiermann, André. Postspektakuläres Theater - Die Alterität der Auffübrung und die Entgrenzung der Künste. Bielefeld: Transcript, 2009).

${ }^{5}$ Arntzen, «Mye står på spill for teatervitenskaps-faget i Bergen»

${ }^{6}$ Ibid.
} 
artikkelen representerer adresserer altså hele det teaterfaglige feltet - i stedet for å avgrense både teatervitenskap som distansert teoretisk forskning fra scenekunstnerisk praksis og det teatervitenskapelige fagmiljøet i Bergen, med dets klassiske fagprofil, fra andre fagmiljøer som representerer teatervitenskap. Det kan derfor antas som ganske sikkert at det var denne andre argumentasjonsmåten som først og fremst dannet grunnlaget for den brede solidariseringen som trengtes for å bevare teatervitenskap i Bergen. (At denne solidariseringen fortsatt trengs for å forsvare teatervitenskap generelt, har sist vist seg da faget ble truet på nytt ved NTNU i Trondheim.)

\section{Hvordan plassere teatervitenskap i forholdet mellom forskning og kunstnerisk utviklingsarbeid?}

I tillegg til de nevnte aspektene som vedrører det teaterfaglige feltet, gjør Arntzens artikkel også sine lesere implisitt oppmerksom på en grunnleggende og alminneligere forskningspolitisk problematikk: Arntzen kritiserer oppfatningen om at forskning skulle holde en viss akademisk avstand til feltet som studeres, og han påpeker at humanioramiljøet, til tross for allerede eksisterende eksempler på forbindelser mellom teori og praksis, «synes [...] å være preget av en forsterkning av elfenbenstårn-tenkning. ${ }^{7}$ Sett i en forskningspolitisk sammenheng kan det som kritiseres her anses som en effekt av den spesifikk norske likestillingen mellom forskning og kunstnerisk utviklingsarbeid, slik den er forankret i Lov om universiteter og hogskoler siden 1995.

Denne likestillingen har uten tvil mange fordeler. Ikke minst er den nok en sentral grunn for at det, som Therese Bjørneboe uttrykker det, «har [...] skjedd en solid tilvekst av ulike utdannelsestilbud på kunsthøgskoler og universiteter» (som absolutt inneholder teatervitenskapelige aspekter og posisjoner), mens «[t]eatervitenskap har vært utsatt for nedlegging og nedleggingstrusler ved de store universitetene.. ${ }^{8}$ Men akkurat denne tilveksten på den ene siden og disse faktiske og truende nedleggingene på den andre siden kan også ses i en problematisk sammenheng, for å ikke si at begge utviklinger betinger hverandre og faktisk har felles årsaker.

Likestillingen mellom forskning og kunstnerisk utviklingsarbeid baserer seg jo på et grunnleggende skille mellom de to, som særlig kommer til uttrykk i valget av begrepet kunstnerisk utviklingsarbeid $\mathrm{i}$ stedet for kunstnerisk forskning. Selve likestillingen er akkurat derfor ikke ukontroversiell. Tvert imot er skillet som ligger til grunn for denne likestillingen ganske omdiskutert. Dette har særlig vist seg i debatten om nettopp begrepsalternativet kunstnerisk utviklingsarbeid og kunstnerisk forskning sett $\mathrm{i}$ sammenheng med opprettelsen av en kunstnerisk doktorgrad i Norge - en debatt som pågikk samtidig som trusselen mot teatervitenskap i Bergen ble akutt (riktignok uten at teatervitenskapelige perspektiver ble særlig synlig i den sammenhengen).

Skillelinjen i denne debatten lå stort sett mellom to posisjoner: På den ene siden ble avgrensningen mellom forskning og kunstnerisk utviklingsarbeid, og særlig valget av begrepet kunstnerisk

\footnotetext{
${ }^{7}$ Ibid.

${ }^{8}$ Bjørneboe, Therese. «Hvem er de?». Norsk Shakespeare- og Teatertidsskrift, nr. 2 (2018), Bonus til nettutgaven. http://shakespearetidsskrift.no/2018/08/hvem-er-de.
} 
utviklingsarbeid, kritisert for å forsterke en utidsmessig dikotomi mellom vitenskap og kunst. ${ }^{9}$ På den andre siden ble denne avgrensningen rettferdiggjort ved å argumentere at denne norske modellen, med alternativet mellom doktorgrader som er enten «på vitenskapelige premisser, fullt og helb), eller «på kunstneriske premisser, fullt og helt», var kvalitetssikrende, særlig sammenlignet med «hybriddoktorgraden» $\mathrm{i}$ andre land. ${ }^{10}$ Det som riktignok manglet i denne rettferdiggjørelsen var en refleksjon over de tilsvarende kvalitetskriteriene - og over spørsmålet hvorvidt deres anvendelse muligens heller bidrar til å konsolidere stereotypiske oppfatninger om både vitenskap og kunst enn å åpne for nødvendige revisjoner av disse oppfatningene i lys av forandringer i begge områder, særlig $\mathrm{i}$ lys av faktiske hybridiseringsutviklinger mellom vitenskap og kunst.

I denne sammenhengen fantes det vel også tilhengere av begrepet kunstnerisk utviklingsarbeid som var enige med begrepets kritikere i at det burde heller fokuseres på berøringspunkter enn på forskjeller mellom kunstnerisk utviklingsarbeid og forskning. ${ }^{11}$ Men samtidig var det akkurat denne posisjonen som så et problem $\mathrm{i}$ «en tendens å lime kunstnerisk utviklingsarbeid sammen med humaniora» $»^{12}$, og som dermed implisitt uttalte seg for å erstatte den generelle avgrensningen mellom kunstnerisk utviklingsarbeid og forskning med en tilspisset avgrensning mellom kunstnerisk utviklingsarbeid og humanistisk forskning.

At særlig en slik skjerpelse står i en vekselvirkningssammenheng med tilsvarende ønsker om avgrensning i humanioramiljøet - at altså ønsket om en tilspisset avgrensning mellom kunstnerisk utviklingsarbeid og humanistisk forskning på den ene siden og humanioras elfenbenstårn-tenkning på den andre siden forsterker hverandre - er mer enn sannsynlig slik jeg ser det. Og det er ganske åpenbart at denne skjerpelsen, i enda høyere grad enn den generelle avgrensningen mellom kunstnerisk utviklingsarbeid og forskning gjør det, bidrar til å frata teatervitenskap, som humanistisk disiplin, relevans for scenekunstnerisk praksis. Dermed kan den selvfølgelig tjene som en veldig velkommen bekreftelse av posisjoner som ønsker å rettferdiggjøre fagets nedleggelse eller nedskjæring, og som leter etter grunner for å kunne erklære teatervitenskap for uviktig. Dessuten kan slike uttalelser også forsterke den dessverre populære oppfatningen at teatervitenskap var annenrangs $\mathrm{i}$ forhold til scenekunst, nærmere bestemt at teatervitenskap var vel avhengig av scenekunst som sin forskningsgjenstand, men at utvikling av scenekunst saktens kunne klare seg uten teatervitenskap.

I lys av debatten om forholdet mellom forskning og kunstnerisk utviklingsarbeid viser det seg altså at det å påpeke, eksemplifisere og formidle teatervitenskapens faktiske relevans for praksisfeltet ikke bare er viktig for å forsvare faget overfor humanioramiljøets elfenbenstårn-tenkning, eller for å mobilisere solidaritet til det teaterfaglige feltet i flere forskjellige områder. Likeså viser blikket på denne debatten at en slik strategi også er viktig for å avkrefte argumenter fra kunstfaglige posisjoner utenfor humanioramiljøet, som frakjenner teatervitenskap relevans. Nærmere bestemt: Det viser at

\footnotetext{
${ }^{9}$ Jf. Aagaard Petersen, Jesper og Tone Pernille Østern. «Kunstskaping eller kunstnerisk utviklingsarbeid?». Scenekunst.no.24.10.2017. http:/ /www.scenekunst.no/sak/kunstskaping-eller-kunstnerisk-utviklingsarbeid/ ${ }_{10}$ Tornquist, Peter og Kjetil Solvik. «Ja, en kunstnerisk doktorgrad er veien å gå». Scenekunst.no. 30.10.2017. http://www.scenekunst.no/sak/ja-en-kunstnerisk-doktorgrad-er-veien-a-ga/

${ }_{11}$ Jf. Mortensen, Jørn og Trond Lossius. «Ph.d. i kunstnerisk utviklingsarbeid - behov for en oppklaring». Scenekunst.no. 31.10.2017 http://www.scenekunst.no/sak/ph-d-i-kunstnerisk-utviklingsarbeid-behov-foren-oppklaring/

${ }^{12}$ Ibid.
} 
denne strategien ikke bare er viktig i forhold til de forskningspuristiske posisjonene innenfor dette miljøet som anser teatervitenskap som for praksisnær. Det viser også at strategien er viktig i forhold til kunstfaglige posisjoner utenfor dette miljøet som, i motsetning til førstnevnte, anser faget som for praksisfjernt, for limet til (kritisk) teori eller, nettopp, for humanistisk - og dermed som relativt irrelevant for utviklingen av scenekunst.

Det som må tydeliggjøres overfor både den ene og den andre av disse posisjonene er at teatervitenskapens spesifikke relevans består akkurat $\mathrm{i}$ at faget er knyttet til både forskning og kunstnerisk utviklingsarbeid. Med andre ord, og i henhold til diskursen om begrepet artistic research: Det må vises at fagets research on the arts (dets forskning $p a ̊$ scenekunst) har en avgjørende betydning for research in the arts (forskning $i$ eller med scenekunst, henholdsvis scenekunstnerisk utviklingsarbeid). ${ }^{13}$ Ikke minst er det viktig å eksemplifisere at teatervitenskap har denne betydningen både som impulsgiver, inspirasjons- eller til og med materialkilde, og som grunnlag og referansepunkt for (selv)kritisk refleksjon, særlig i forhold til og i oppgjør med stereotypiske oppfatninger.

Særlig i denne sammenhengen virker tanken om at én institusjon alene kunne sikre teatervitenskapens eksistens like så urealistisk som tanken om at én institusjon alene kunne realisere idealet om en forskningsfront i skjæringspunktet mellom teori og praksis. Det som etter mitt skjønn er avgjørende for å bevare teatervitenskap som et levende fag (og det betyr også å ikke bare «bevare» det i en konservativ forstand, men også å bevege faget videre), er å forsvare og fremme et mangfold og et nettverk av forskjellige teatervitenskapelige fagmiljøer, som sammen - med deres ulike måter å sette teori og praksis i forhold til hverandre - danner et felt hvor tverrgående teori- og praksislinjer kan treffes i flere skjæringspunkter. ${ }^{14}$

Slike skjæringspunkter kan oppstå i form av hendelser som konferansen i Bergen. De kan også slik de ofte gjør - bestå $i$ at teatervitere samarbeider som dramaturger med scenekunstnere, som vitenskapelige eksperter ved siden av kunstneriske eksperter, så å si. Like så kan de bestå $\mathrm{i}$ at de kunstneriske bidragene til festivalprogrammer ledsages av diskursprogrammer, hvor teatervitere drøfter, ofte i dialog med kunstnerne, disse bidragene fra deres vitenskapelige perspektiver og/eller tilføyer vitenskapelig kunnskap. Kort (og litt simplifisert) sagt: Slike skjæringspunkter kan bestå i møter, samarbeider og dialoger mellom teatervitere (henholdsvis teoretikere) på den ene siden og scenekunstnere (henholdsvis praktikere) på den andre siden.

Men skjæringspunkter mellom teori og praksis (som etter mitt skjønn uansett burde heller anses som to sider av samme sak) kan likeså ligge i én og samme person og i individuelle arbeidsmåter, og slike skjæringspunkter kan på en særlig måte eksemplifisere hva denne artikkelen skal vise: At teatervitenskap kan, også uavhengig av (men selvfølgelig særlig i forbindelse med) at teatervitere er

\footnotetext{
${ }^{13} \mathrm{Jeg}$ refererer her til Henk Borgdorffs skille mellom research on the arts, research for the arts og research in the arts (Borgdorff, Henk. The Debate on Research in the Arts, Sensuous Knowledge no 2. Bergen: Kunsthøgskolen i Bergen, 2006, 12). Begrepet kunstnerisk utviklingsarbeid er «i Norge [...] i overenstemmelse med kategorien research in the arts) (Malterud, Nina, Torben Lai, Aslaug Nyrnes og Frode Thorsen. Forskning og utviklingsarbeid innen fagområdet kunst. 1995-2015: 20 ar med kunstnerisk utviklingsarbeid. Oslo: UHR, 2015. https://www.uhr.no/ f/p1/i276102cc-6251-4224-81d0-2029453909f3/2015-

forskning_og_utviklingsarbeid_innen_fagomr_det_kunst.pdf).

${ }^{14} \mathrm{Jf}$. Eiermann. «Behovet for dynamikk».
} 
involvert, virke som et produktivt element i skapende scenekunstneriske prosesser. Ikke minst kan en med henblikk på slike tilfeller særlig tydelig vise at teatervitenskap kan virke slik på flere måter. Én måte kan være å fungere som en vitenskapelig diskurs som kunstnere refererer og forholder seg til i deres arbeider, og som sånn kan virke som impulsgiver, inspirasjons- eller til og med materialkilde. En annen måte kan være å fungere som grunnlag og referansepunkt for kunstnernes kritiske refleksjon, både refleksjonen over deres egen kunstnerisk praksis og refleksjonen over stereotypiske oppfatninger om kunst og andre samfunnsmessige aspekter. Kort sagt: Det som i det følgende skal eksemplifiseres er at teatervitenskap, som vitenskapelig diskurs, har en performativ kraft i forhold til scenekunst.

\section{Teatervitenskapens performative kraft}

Akkurat den performative kraften utgjør grunnlaget for denne artikkelens tittel: Hvordan gjore scenekunst med teatervitenskap, som er en hentydning til John L. Austins språkhandlingsteoretiske hovedverk How to do Things with Words (1975) - den mest grunnleggende referansen for teatervitenskapens diskurs om performativitet. ${ }^{15}$ Gjennom denne referansen skal altså det som Austin sier om ord også sies om teatervitenskap som diskurs. Det vil si: Slik som Austin har vist at det å si noe betyr ikke bare å si noe om ting, men også å faktisk gjøre ting, skal artikkelens tittel vise til at teatervitenskap er ikke bare en diskurs om scenekunst, men at denne diskursen også kan gjøre scenekunst. Eller for å si (henholdsvis gjøre) det en gang til med andre ord: Det som i det følgende skal eksemplifiseres er at teatervitenskap ikke bare består i forskning på scenekunst, men at den også er (ikke bare som kompetanse hos teatervitere, men først og fremst som diskurs) delaktig og performativ medvirkende i skapende scenekunstneriske utviklingsprosesser.

Som vitenskapelig diskurs er teatervitenskap selvfølgelig - og det virker nesten rart å si det - ikke bare tilgjengelig for teatervitere. Selvsagt kan teatervitere gjøre krav på å ha en særlig kunnskap og ekspertise om denne diskursen (noe som ikke minst er grunnlaget for at de kan oppnå en særlig definisjonsmakt i henhold til teaterfaglige spørsmål). Det er også klart at det fins teatervitenskapelige spesialdiskurser som er ikke umiddelbart tilgjengelig eller forståelig for utenforstående. Men i prinsippet er teatervitenskap som vitenskapelig diskurs et område med åpne grenser. Den er tilgjengelig utenfra gjennom nettopp diskursens manifestasjoner. (Ovennevnte diskursprogram i festivaler er særskilte eksempler på hvordan denne tilgjengeligheten kan benyttes.) Det samme gjelder for ytterligere vitenskapelige diskurser som den teatervitenskapelige diskursen forholder seg til. Og særlig scenekunstnere som er interessert i kritisk refleksjon og i å utfordre

\footnotetext{
${ }^{15}$ Det samme gjelder min bruk av begrepet performativ kraft, som jeg riktignok ikke låner direkte fra Austin. Austin erstatter - i løpet av forelesningene som danner How to do Things with Words, nærmere bestemt i den åttende forelesningen - sitt skille mellom konstative og performative ytringer med skillet mellom lokusjonære, illokusjonære og perlokusjonære aspekter som, ifølge han, gjelder alle språklige ytringer. I denne sammenhengen snakker han om en illokusjonær kraft (jf. Austin, John Langshaw. How to do Things with Words. London, Oxford: Clarendon, 1975). Siden dette aspektet riktignok tilsvarer det som han opprinnelig siktet på å eksemplifisere med beskrivelsen av performative ytringer, har begrepet «performativ kraft» etablert seg som synonym til illokusjonær kraft i diskusjonen om Austins språkhandlingsteori og den videre teoriutviklingen som refererer seg til den.
} 
stereotypiske oppfatninger - ikke minst stereotypiske oppfatninger om forholdet mellom vitenskap og kunst - benytter seg intensivt av disse åpne grensene.

De to kunstnere hvis arbeider skal drøftes i det følgende, Mette Ingvartsen og Iggy Malmborg, er begge eksempler på akkurat denne typen scenekunstnere. De kan til og med kalles for ganske ekstraordinære eksemplarer av denne scenekunstnertypen. Blikket på deres arbeider og arbeidsmåter kan derfor særlig tydelig eksemplifisere kjennemerker som i dag preger de formene for scenekunstnerisk virksomhet som forstår seg selv som kritisk og nyskapende virksomhet, og setter spørsmålstegn ved stereotypiske oppfatninger.

\section{Forbindelser med teatervitenskap}

Verken Ingvartsen eller Malmborg er utdannet i teatervitenskap. Ingvartsen er en dansk danser og koreograf med utdannelse fra scenekunstskolen P.A.R.T.S. (Performing Arts, Research and Training Studios) i Brussel, hvor hun tok eksamen i 2004. Malmborg er en svensk skuespiller og performanceskaper som har studert skuespillkunst ved Teaterhögskolan i Malmö ved Lunds Universitet fra 2006 til 2010. Likevel arbeider begge to - ikke minst fordi utdanningene deres er preget av forbindelser mellom praksis og teori ${ }^{16}$ - ikke bare $i$ et nært forhold til, men faktisk i tette forbindelser med teatervitenskapelige, performanceteoretiske og andre vitenskapelige diskurser. Dette viser ikke bare de kunstneriske arbeidene deres, men også deres refleksjoner over disse. I begges virke tar disse refleksjonene form både som del av det kunstneriske utviklingsarbeidet og som etterfølgende overveielser over dette arbeidets resultater. Og begge kunstnere har publisert, og publiserer fortløpende, disse refleksjonene i form av mangfoldige tekster, intervjuer og foredrag.

Ingvartsen har bl.a. skrevet en rekke artikler og selvintervjuer - delvis publisert i faglige tidsskrifter og tilgjengelig på eller via hennes hjemmeside ${ }^{17}$ - samt monografien The Artificial Nature Series (2016) om hennes koreografisyklus av samme navn. Denne monografien var del av hennes kunstneriske Ph.d.-prosjekt i koreografi med tittelen EXPANDED CHOREOGRAPHY: Shifting the agency of movement in The Artificial Nature Project and 69 positions, ${ }^{18}$ gjennomført i rammen av forskerutdanningen til Stockholms Konstnärliga Högskola / UNIARTS, og presentert ved Lunds Universitet i Malmö. Hennes forskende virksomhet framheves også eksplisitt i hennes faglige

\footnotetext{
${ }^{16}$ Mønsterplanen til P.A.R.T.S. bestod, da Ingvartsen studerte der, i to toårige faser, kallet for Training Cycle og Research Cycle (jf. P.A.R.T.S. «School.» 2020. https://www.parts.be/about), som begge var preget av forbindelsen mellom praksis og teori. I beskrivelsen til den fremdeles eksisterende Training Cycle nevnes «theoretical reflection» ved siden av trening i praktiske ferdigheter som del av studiet. I beskrivelsen til etterfølgeren av Research Cycle, som i dag heter STUDIOS program, ligger fokuset på «research and artistic research», og studiet omfatter bl.a. «movement research workshops, theory seminars and [...] individual research» (P.A.R.T.S. «Program.» 2020. https://www.parts.be/programme-1). Skuespillerutdanningen ved Teaterhögskolan i Malmö omfatter teoretiske undervisningsdeler som har hensikten «att undersöka, problematisera och presentera hur teaterns olika delar kan förena teori och praktik i samspel med den tid vi lever i» (Teaterhögskolan i Malmö. «Skådespelarprogrammet.» https://www.thm.lu.se/program-ochkurser/konstnarligt-kandidatprogram-i-skadespelarkonst-180-hp).

17 Ingvartsen, Mette. «Texts \& Interviews,» Mette Ingvartsen. 2020. https://www.metteingvartsen.net/texts-and-interviews/

${ }^{18}$ Ingvartsen, Mette. EXPANDED CHOREOGRAPHY: Shifting the agency of movement in The Artificial Nature Project and 69 positions. Doktoravhandling. Stockholms Konstnärliga Högskola, Stockholm / Lunds Universitet, Malmö. 2016.
} 
selvpresentasjon. Så fins det på hennes hjemmeside en egen seksjon om Research Projects, og biografien opplyser om at hennes virke omfatter, ved siden av «making, performing, writing and lecturing», også «teaching and sharing research through workshops with students at universities and art schools.» ${ }^{19}$

Malmborg underviser og foreleser like så i akademiske kontekster, bl.a. ved Stockholms Konstnärliga Högskola og Teaterhögskolan i Malmö. Han bidrar også, i forbindelse med presentasjoner av de kunstneriske prosjektene sine, aktivt til diskursprogrammer, både i form av foredrag, intervjuer, samtaler og tekster. Eksempler er hans artikkel Towards Coprolalia (2019), som ble publisert av Black Box teater i Oslo og reflekterer over hans performance Physics and Phantasma fra 2017, ${ }^{20}$ samt hans foredrag om samme performance i rammen av seminaret Unveiling the dark corners under Oslo Internasjonale Teaterfestival 2019. Et ytterligere eksempel kunne vært samtalen Skuespillerkunst $i$ kontekst med teaterviter Tor Trolie ved BIT Teatergarasjen. Denne samtalen var planlagt for mars 2020, men måtte avlyses på grunn av koronakrisen - sammen med forestillinger av Physics and Phantasma og Malmborgs siste produksjon Things in my mouth (2019), som samtalen skulle stå i sammenheng med.

Forbindelsen mellom teori og praksis, som kjennetegner disse to scenekunstnerne på en særlig måte, er riktignok ikke den eneste grunnen for at jeg har valgt deres arbeider som eksempler på teatervitenskapens performative kraft i forhold til scenekunst. Det fins to ytterligere grunner, og den første av disse ble nettopp indirekte angitt ved å omtale den avlyste samtalen med Malmborg og de avlyste forestillingene av hans arbeider som skulle finne sted ved BIT Teatergarasjen. Slik som Malmborgs arbeider ved denne anledningen skulle vises der for første gang, så har også Ingvartsens arbeider blitt vist der over flere år - faktisk allerede siden 2004. Og slik som Malmborgs siste produksjon Things in my mouth, så ble også flere av Ingvartsens arbeider koprodusert av BIT Teatergarasjen. Begge kunstnere står altså i et tett forhold til denne institusjonen, som igjen står i et tett forhold til det teatervitenskapelige fagmiljøet i Bergen. Utover det er både Ingvartsen og Malmborg også knyttet til flere scenekunstinstitusjoner i Norge: Malmborgs arbeider har blitt vist, som nevnt, ved Black Box teater i Oslo, samt ved Rosendal teater (tidligere Teaterhuset Avant Garden) i Trondheim, og begge hus har vært koprodusenter i denne sammenhengen. Ingvartsens arbeider har likeså blitt vist ved Black Box teater, samt ved Dansens hus i Oslo (som også var koprodusent) og RIMI/IMIR Scenekunst i Stavanger. Begge kunstneres arbeider har altså gitt impulser til det norske scenekunstmiljøet i de siste årene, og særlig deres forbindelse med miljøet i Bergen er enda en grunn for å fokusere på deres arbeider i denne artikkelen.

Den andre grunnen er simpelthen den eksisterende forbindelsen mellom begges arbeider og min forskning: Ingvartsen møtte jeg først i 2003, da hennes P.A.R.T.S.-klasse besøkte Institut für Angewandte Theaterwisssenschaft i Giessen (Tyskland) hvor jeg var student. Ved denne anledningen viste hun sitt arbeid Solo Negatives (2002), og Christina Hänsel og jeg viste vår performance-trilogi NO MORE THEATRE (2002). Siden da har jeg fulgt med i Ingvartsens arbeid

\footnotetext{
${ }^{19}$ Ingvartsen, Mette. «Biography,» Mette Ingvartsen. 2020. https://www.metteingvartsen.net/biography/

${ }^{20}$ Lond Malmborg, Iggy. «Towards Coprolalia». I Black Box teater - Publikasjon 3 / Publikasjon 3, redigert av Elin Amundsen Grinaker og Anne-Cécile Sibué-Birkeland. 81-100. Oslo: Black Box teater, 2019.
} 
og i flere sammenhenger skrevet om det ${ }^{21}$, bl.a. om 69 positions ${ }^{22}$, som skal drøftes i det påfølgende. Malmborg ble jeg kjent med i 2015 under Bastard festivalen i Trondheim, hvor jeg for første gang så hans performance $b$ o n e r-det andre arbeidet som jeg skal referere meg til. Siden da har jeg vært i dialog med ham, og har både skrevet om hans arbeider ${ }^{23}$ og samarbeidet kunstnerisk med ham. ${ }^{24}$

Dermed (samt ved å nevne performance-trilogien NO MORE THEATRE) har jeg også allerede sagt noe annet om min forskning, nemlig at den står i forhold til egen scenekunstnerisk virksomhet. Faktisk kan jeg ikke beskrive det ene på en tilstrekkelig måte uten å snakke om det andre. I forhold til Ingvartsens og Malmborgs arbeider kan min teatervitenskapelige virksomhet for størstedelen vel beskrives som forskning $p a ̊$ scenekunst (eller research on the arts). I sin helhelt er denne virksomheten riktignok preget av en tett forbindelse mellom forskning og kunstnerisk utviklingsarbeid. Research on the arts og research in the arts er ofte konkret flettet sammen. Selv i de sammenhengene hvor research on the arts står i forgrunnen, er både min forskerholdning og mine forskningsmåter preget av denne forbindelsen. Før jeg går inn på Ingvartsens 69 positions i forhold til historiografifokuset (under «Hvordan gjøre koreografi med historiografi») og på Malmborgs b o n e r i forhold til teorifokuset (under «Hvordan gjøre teater med teori»), vil jeg derfor - i forhold til praksisfokuset - gi et innblikk i min egen virksomhet og måten den er preget av nevnte forbindelse. Dette skal riktignok ikke skje uten å komplisere den tilsvarende delens overskrift litt ved å formulere det slik:

\section{Hvordan gjøre teatervitenskap med praksis eller Hvordan gjøre scenekunst med anvendt teatervitenskap}

At jeg har nevnt performance-trilogien NO MORE THEATRE - samt møtet eller dialogen mellom denne trilogien og Ingvartsens Solo Negatives i Giessen - har, slik som valget av 69 positions og $b$ o n e r som eksempler, flere grunner. Den første grunnen er at utviklingen av denne trilogien kan, som allerede vist et annet sted, ${ }^{25}$ retrospektiv sett beskrives som begynnelse, eller utgangspunkt avant la lettre, av min forskning om og mitt arbeid med slike scenekunstformer som jeg senere skulle beskrive som postspektakulært teater. Med andre ord: Trilogien kan beskrives som begynnelsen av

\footnotetext{
${ }^{21} \mathrm{Jf}$. Eiermann. Postspektakuläres Theater, samt Eiermann, André. «Pleasures to come». I herbst. Theorie zur Praxis, redigert av Martin Baasch, Flori Gugger, Andreas R. Peternell og Thomas Wolkinger. 101-103. Graz: steirischer herbst festival, 2015.

${ }^{22}$ Jf. Eiermann, André. «A postspectacular perspective on 〈relational aesthetics» and audience participation.» I Framing a Mirage. Communicating contemporary art and its values, redigert av Karoline Skuseth. 95-132. Bergen: BIT Teatergarasjen \& APAP - advancing performing arts project, 2015.

${ }^{23} \mathrm{Jf}$. Eiermann, André. «Wenn ich möchte, dass Schauspielstudierende nachdenklich werden, geb’ ich ihnen einen Text von Heiner Goebbels». I Landschaft mit entfernten Verwandten - Festschrift für Heiner Goebbels, redigert av Lorenz Aggermann, Eva Holling, Philipp Schulte, Bernhard Siebert, Gerald Siegmund og Katharina Stephan. 129-140. Berlin: Neofelis, 2018; samt Eiermann, André. «I HATE THEATRE - IT’S JUST ILLUSION. Eine Praktik des Scheins als kritische Praxis: Zur Ironisierung anti-illusionistischer Topoi in Iggy und Maike Lond Malmborgs Performance 99 Words for Void». I Theater als Kritik: Theorie, Geschichte und Praktiken der Ent-Unterwerfung, redigert av Olivia Ebert, Eva Holling, Nikolaus Müller-Schöll, Philipp Schulte, Bernhard Siebert og Gerald Siegmund. 103-110. Bielefeld: Transcript, 2018.

${ }^{24}$ Det tilsvarende samarbeidet var et prosjekt med tittelen ONE, TWO, THREE, FIVE..., som vi utviklet sammen med masterstudenter i kunstfag ved Universitetet i Agder. Prosjektet ble presentert på 06.09.2020 i Kristiansand Kunsthall.

${ }^{25}$ Jf. Eiermann og Frøysnes, «Hva kan teater være?».
} 
en teatervitenskapelig forskningsprosess i form av et scenekunstnerisk utviklingsarbeid - eller: som et eksempel på hvordan gjøre teatervitenskap med praksis. Den andre grunnen er at trilogiens første to deler, NO og MORE, ble utviklet i Bergen, mens Hänsel og jeg var utvekslingsstudenter i teatervitenskap der i 2001. De ble først vist i Prøverommet-programmet ved BIT Teatergarasjen, hvor vi også arbeidet som frivillige under utvekslingsstudiet vårt. Det var Knut Ove Arntzen som den gang hadde formidlet kontakten til BIT Teatergarasjen - og dette er én av de mange grunnene for at påstanden om at teatervitenskap i Bergen var kun teorirettet høres, selv om praktiske aspekter er ikke del av mønsterplanen til studiet der, ikke veldig overbevisende ut for meg.

Men NO MORE THEATRE kan ikke bare sees som et eksempel på hvordan gjøre teatervitenskap med praksis. For liksom det er det, så var vår scenekunstnerisk praksis selvfølgelig også allerede ved trilogiens utvikling preget av vårt teatervitenskapelige studium. Det scenekunstneriske utviklingsarbeidet bestod faktisk - i samsvar med profilen til vår utdanning i Giessen - i en anvendelse av teatervitenskap. Det vil si: Trilogien er også et eksempel på hvordan gjøre scenekunst med anvendt teatervitenskap.

Denne anvendelsen tok form i flere aspekter. For eksempel refererte trilogien, i form av både tekstuelle og visuelle sitater og hentydninger, til flere kunstneriske posisjoner og estetikker som hadde vært tema i studiet vårt. I NO ble den teatervitenskapelige bakgrunnen i tillegg synlig som hentydning til vitenskapelig kildebruk, idet de tilsvarende kunstnerne (Gertrude Stein, Jérôme Bel, Forced Entertainment og bandet No Doubt) ble eksplisitt angitt ved å presentere deres navn skrevet på et pappskilt. Disse skiltene, som i seg selv var en referanse til Forced Entertainments estetikk, fungerte altså samtidig som scenografiske kildehenvisninger, så å si. I tillegg var også vår bruk av skrift inspirert av perspektiver som vi hadde blitt kjent med gjennom studiet - og derfor preget av et semiotisk blikk på arbitrariteten og differensialiteten til språklige tegn, en fenomenologisk oppmerksomhet på signifikantenes materialitet, samt ikke minst en interesse i språkets (og i dette tilfellet særlig skriftens) performative dimensjon og muligheten å gjøre ting med ord. NO begynte, mens både scene og sal fremdeles var lyst opp av arbeidslys, idet jeg først presenterte akkurat denne tittelen, også skrevet på et pappskilt. Så snudde jeg dette skiltet, hvorved «NO» ble til «ON». Dette utløste et lysskift fra arbeidslys til en enkelt spot på min posisjon, fulgt av at jeg skrev en $E$ bak «ON», som sånn forvandlet seg til «ONE». Så opptrådte Hänsel, med et pappskilt med påskriften «TWO», fulgt av at en annen spot lyste opp for henne, og så videre. ${ }^{26}$

Med denne måten å gjøre teatervitenskap med praksis - og scenekunst med anvendt teatervitenskap - fortsatte vi i form av flere performanceprosjekter. Da jeg begynte mitt arbeid på doktoravhandlingen min var det vårt prosjekt GEMISCHTES DOPPEL (2005) som stod i en direkte forbindelse og i en konkret vekselvirkning med den: Avhandlingen tok sitt utgangspunkt i beskrivelsen av dette prosjektets første versjon. I prosjektets andre versjon fra 2006 - en performance-lecture - brukte vi en variasjon av denne beskrivelsen som del av foredragsteksten (samt flere tematiske aspekter av avhandlingen som denne tekstens innhold). Og avhandlingen gikk

${ }^{26}$ For nærmere beskrivelser av NO MORE THEATRE, se Witzeling, Klaus. «NO MORE THEATRE. Eine Performance-Trilogie. Die Inszenierung in der Kritik». I Sz̨ene machen. Das Körber Studio Junge Regie, redigert av Nikolaus Besch, Susanne Kutz og Dirk Wegner. 30-32. Hamburg: edition Körber Stiftung, 2004; samt Evert, Kerstin. «Die Theatermacher». I tan₹.de - Zeitgenössischer Tan₹ in Deutschland - Strukturen im Wandel - eine neue Wissenschaft. Arbeitsbuch 2005, redigert av Johannes Odenthal og Nina Peters. 164-166. Berlin: Theater der Zeit, 2005. 
så til slutt, i dens siste kapittel, igjen inn på denne andre versjonen av prosjektet, på bakgrunn av og i forhold til det som jeg hadde skrevet om andre eksempler på et postspektakulært teater i de foregående kapitlene. Scenekunstnerisk utviklingsarbeid og teatervitenskapelig forskning var i dette tilfellet altså på tetteste måte flettet sammen. På enda tydeligere måte enn NO MORE THEATRE var GEMISCHTES DOPPEL dermed et eksempel på hvordan å gjøre både teatervitenskap med praksis og scenekunst med anvendt teatervitenskap.

Denne forbindelsen mellom teatervitenskapelig forskning og scenekunstnerisk utviklingsarbeid samt festivalene Oktoberdans og Meteor av BIT Teatergarasjen - var også grunnen for mitt samarbeid som dramaturg med Heine Avdal og Yukiko Shinozaki / fieldworks. Vi hadde møtt hverandre først i 2012 ved PACT Zollverein Essen (Tyskland). Jeg hadde sett deres produksjon Field Works-office fra 2010 der, og tok ved den anledningen kontakt med dem fordi jeg var interessert $\mathrm{i}$ deres arbeid i sammenheng med min forskning om illusjon i samtidsteater. Under Oktoberdans-festival 2012 møttes vi igjen, og særlig under Meteor-festival 2013 ble vi bedre kjent med hverandre. I denne sammenhengen hørte Avdal og Shinozaki også mitt foredrag Theoretical Reflections on the Postspectacular, som drøftet bl.a. Hänsels og mitt prosjekt NOTHING IS HAPPENING fra 2008. ${ }^{27}$ Foredraget var et bidrag til The Triangle Seminar: Bergen - Arbus - St. Petersburg, arrangert av festivalen og seksjon for teatervitenskap ved Universitetet i Bergen, og etter det foreslo Avdal og Shinozaki å samarbeide. Slik som festivalene var anledninger for meg å bli kjent med flere av deres scenekunstneriske arbeider, så var altså seminaret anledningen for dem å bli kjent med min måte å drive med anvendt teatervitenskap. Og dette må selvfølgelig nevnes her, siden det er et eksempel på hvor viktig teatervitenskapelige arrangementer i rammen av scenekunstfestivaler (og slike festivaler generelt) er for at nye samarbeidskonstellasjoner kan oppstå og nye scenekunstprosjekter kan initieres.

Det som Avdal og Shinozaki var eksplisitt interessert i, var å «think and do together». ${ }^{28}$ Så, i stedet for en klassisk arbeidsdeling mellom scenekunstnerne som praktikere på den ene siden og teaterviter-dramaturgen som teoretiker på den andre siden var det akkurat forbindelsen mellom praksis og teori i en felles arbeidsprosess som de så for seg. Dette passet selvfølgelig mer enn bra sammen med min måte å arbeide på i skjæringspunktet mellom teatervitenskapelig forskning og scenekunstnerisk utviklingsarbeid. Mine bidrag til våre samarbeidsprosjekter baserte seg tilsvarende på både mine kunstneriske og vitenskapelige erfaringer.

At vi valgte å arbeide med kubiske objekter i både distant voices, vårt første samarbeidsprosjekt fra 2014, og carry on, det påfølgende prosjektet fra $2015,{ }^{29}$ stod for eksempel i sammenheng med min

\footnotetext{
${ }^{27}$ Prosjektet ble først utviklet som begynnelse av et annet prosjekt med tittelen ALPHA ALPHA i 2004. Som separat prosjekt er NOTHING IS HAPPENING en interaktiv sceneinstallasjon.

${ }_{28}$ Personlig kommunikasjon i e-post fra Heine Avdal, 19.12.2013.

${ }^{29}$ I distant voices er det femti hvite kuber (derav tjue som kan lyse opp og gjengi lyd), som utøverne beveger seg med og i forholdt til. Disse kubene danner, som mobile elementer, en modulær og bevegelig scenografi eller scenisk installasjon, som forandrer seg i løpet av forestillingen ved at utøverne bygger forskjellige strukturer med kubene. På denne måten forandres også rommets oppdeling, som igjen har effekt for hvordan tilskuerne forholder og beveger seg. (Det fins verken en oppdeling mellom scene og sal eller et amfi i distant voices, men bare de forskjellige og efemeriske oppdelingene av rommet som etterhvert oppstår i løpet av forestillingen på grunn av dens mobile kube-scenografien sine forandringer.) I carry on, en vandreforestilling som til enhver tid utvikles på nytt i forhold til de spesifikke bygningene den realiseres $i$, gjenbrukes de hvite kubene fra distant voices av og til. Men i hovedsaken er det små svarte kuber som er
} 
referanse til diskursen om Minimal Art, som hadde vært av sentral betydning for drøftingen av objekt-begrepet i Postspektakuläres Theater. ${ }^{30}$ Dette valget koblet jeg da, i tekstutviklingsprosessen til distant voices, sammen med min interesse for kombinatorisk lek med språklige tegn, nærmere bestemt bokstaver. Faktisk var dette den logiske konsekvensen av hvordan denne interessen hadde utviklet seg tidligere i mitt scenekunstneriske samarbeid med Hänsel. I NO MORE THEATRE hadde den, som vist ovenfor, særlig preget prosjektets første del. I NOTHING IS HAPPENING overlot vi den kombinatoriske leken med bokstaver - i dette tilfellet atten bokstavobjekter som danner tittelen på scenen - til publikum. ${ }^{31}$ I vårt prosjekt MORPHING MORPHEMES utviklet vi objekter som danner forskjellige morfem-kombinasjoner og er i seg selv tredimensjonale bokstavkoblinger: To bokstaver danner to motstående sider av hvert objekt og definerer dermed samtidig objektets andre sider - som forbindelse mellom dem og deres overgang i hverandre.

Det var dette designet til MORPHING MORPHEMES som så, i samarbeidet med Avdal og Shinozaki, og i samspill med referansen til de kubiske objektene vi arbeidet med i distant voices, dannet grunnlaget for utviklingen av små hvite kubiske bokstavobjekter. Disse bruktes da, bokstavelig talt, som tekstbyggeklosser i forestillingene - både i arbeidspresentasjoner av distant voices og i prosjektets endelige resultat (slik som de større kubene ble brukt som scenografibyggeklosser). Teksten til prosjektets endelige versjon utviklet jeg igjen på basis av referansen til diskursen om Minimal Art. Nærmere bestemt brukte jeg et sitat fra konseptkunstner Sol Le Witt sin tekst Paragraphs on Conceptual Art fra 1967: «Different people will understand the same thing in a different way.» ${ }^{32}$ I forestillingen ble dette sitatet først sammensatt av enkle ord som, fordelt utover rommet, ble dannet med bokstavobjektene. Sitatet selv dannet igjen utgangspunktet for en kombinatorisk utvikling og utbredelse av den påfølgende teksten gjennom rommet. Dette skjedde idet utøverne brukte bokstavobjektene for etterhvert å bygge nye ord med dem (sånn at de ordene som bokstavobjektene ble tatt fra samtidig forsvant igjen eller ble fragmentert). ${ }^{33}$

sentralt i dette prosjektet. Disse svarte kubene dukker i carry on opp fra forskjellige steder i løpet av forestillingen og fungerer som en slags vei-ledemotiv: Utøverne «finner» disse kubene hist og her, plukker dem opp, tar dem med seg, og lar dem forsvinne igjen - eller forsvinner med dem - før flere kuber og/eller aktører dukker opp fra andre steder. (Disse svarte kubene stammer faktisk også fra arbeidsprosessen til distant voices, hvor de opprinnelig ble brukt som modell for dette prosjektets mobile kube-scenografi, men også som sceniske elementer i prosjektets arbeidspresentasjoner. Også vandreforestillingsprinsippet til carry on ble opprinnelig prøvd ut i den første av disse arbeidspresentasjonene).

${ }^{30}$ I tillegg er disse kubene referanser til begrepene white cube og black box, og forholder seg på denne måten til spørsmål og oppfatninger om kunstens forhold til rom, arkitektur, institusjonelle kontekster og stedsspesifikk - henholdsvis til disse aspektenes forhold til kunst.

${ }^{31}$ Utgangssituasjonen i NOTHING IS HAPPENING er at tittelen - i form av disse atten bokstavobjektene, laget av papp - står på scenen, mens tilskuerne sitter i amfi. Hver av dem er utstyrt med en liten hvit ball, som de finner på plassene deres når de kommer inn. Bortsett fra det som tilskuerne gjør skjer faktisk ingenting i denne situasjonen, som i prinsippet ikke er tidsbegrenset og først slutter når den siste tilskueren forlater rommet. Som regel utvikler seg situasjonen slik at tilskuerne, tidligere eller senere, kaster ballene på bokstavobjektene, og at de til sist går på scenen for å bygge opp nye ord (og kaste ballene på de igjen, osv.). For en beskrivelse av NOTHING IS HAPPENING se Ullerup Schmidt, Cecilie. "Carrying Voices Producing Subjects on Stage in Reality». I who's there? - subjects on stage in reality, redigert av Miriam Frandsen og Cecilie Ullerup Schmidt. 12-23. København: The Danish National School of Theatre and Contemporary Dance - Continuing Education, 2011.

${ }^{32}$ Le Witt, Sol. «Paragraphs on Conceptual Art». Arfforum Vol. 5, nr. 10 (1967): 79-83.

33 Tekstens ordlyd, eller heller ordsyn, som i tillegg til sitatet fra Le Witt også inneholder et fragmentert og lett forandret sitat fra Laurie Andersons låt Born, Never Asked fra hennes debut-album Big Science (1982), 
Bokstavobjektene og den kombinatoriske måten å skrive eller bygge tekst med dem på ble så også brukt i carry on. Siden prosjektets femte versjon, som vi realiserte under Oktoberdans-festivalen 2016 i Sentralbadet i Bergen, har dette særlig preget forestillingens begynnelse. For denne versjonen utviklet jeg bl.a. en tekst som åpnet forestillingen ved å referere seg til den kontroversielle debatten om Sentralbadet vedrørende spørsmålet om det kunne bli Bergens nye scenekunsthus for BIT Teatergarasjen og Carte Blanche. Denne teksten, framført av Avdal og meg, bestod kun av de bokstavene som fins i ordet SENTRALBADET (samt én svart kube som både stod for seg selv og fungerte som vikar for forskjellige bokstaver). Dette viste seg $\mathrm{i}$ forestillingen ved tekstsekvensens slutt, som bestod i at dette ordet ble dannet. ${ }^{34}$ Prinsippet ble siden også anvendt i andre versjoner av carry on, og teksten ble tilsvarende variert $i$ henhold til disse versjonenes spesifikke kontekster.

I vårt tredje samarbeidsprosjekt, unannounced fra 2017, arbeidet jeg, i stedet for bokstavobjekter, med skrift- og bokstavprojeksjoner på en liknende måte. Disse projiseres av fem små bærbare prosjektører, som utøverne først bruker for å lede publikumet i små grupper og på forskjellige veier gjennom teaterbygningen, ved å projisere tekst på og langs bygningens arkitektur og interiør. ${ }^{35}$ Senere, når publikumsgruppene og utøverne er samlet på teaterrommets scene, projiserer de sammen en tekst på dette rommets vegger og særlig på det store hvite teppet foran bakveggen, som er forestillingens scenografiske hovedelement.

I denne sekvensen er det først enkle bokstaver som hver prosjektør projiserer, og som utøverne kombinerer til forskjellige ord mens flere og flere bokstaver blir (og forblir) synlige. Slik utvikler det seg på suksessivt vis en tekst, dens ord dannes, slik som i distant voices, mens og ved at de ordene som ble dannet før forsvinner, oppløses eller fragmenteres igjen. ${ }^{36}$ Samtidig viser det seg etterhvert

utvikler seg slik (men kan her ikke gjengis i alle sine aspekter, særlig ikke i de fragmenterende): DIFFERENT PEOPLE WILL UNDERSTAND THE SAME THING IN A DIFFERENT WAY / IT / IS IT / THIS IS IT / OR / IS IT / MORE / OR / LESS / IS IT OVER / IT IS OVER / UNLESS / WE / STAY / HERE / IN / A / ROOM / FULL / OF / PEOPLE / ASKING / THE SAME / QUESTION / WHAT / IS / BEHIND / THIS / CURTAIN (dette refererer seg til teppet bakfra det kubene først dukker opp i forestillingen).

${ }^{34}$ Teksten utvikler seg slik (den svarte kuben framstilles her som $\square$ når den står for seg selv, og når den fungerer som bokstavvikar sammen med den tilsvarende bokstaven i hvit skrift): / A / AND / AND LET / AND LET/S / SEE / AND LETTERS / A AND LETTERS / ARE/ AREA/ AREAL / A REAL / EST/ A RE AL ESTATE / A RELATED DE/B/ATE / A SALE / OR / NO T A SALE / TRADE / OR ART / NO / DEAL / SEALED / AT / LEA/ST / LET S / DARE / A / TEST / AND / ENTER / A / AN / ABSENT / THEATRE / Q / R L / TR LB / NTR LBA / ENTR LBAD / SENTR A LBADET / SENTRALBADET.

35 Denne måten å bruke tekstprojeksjoner på, utviklet jeg i sammenheng med dokumentasjonen av prosjektets arbeidsprosess, nærmere bestemt som grunnleggende prinsipp til en serie dokumentasjonsvideoer med tittelen Logbook 1-8, som jeg lagte i samarbeid med Julie Pfleiderer. Disse videoene er tilgjengelige på http://unannounced.club.

36 Teksten utvikler seg slik: NOW / WE ARE HERE / ALL TOGETHER / IN THE SAME SPACE / AT THE SAME TIME / A PERSON / ENTERS / A ROOM / NOT THIS ROOM / ANOTHER ROOM / IN ANOTHER / BUILDING / THE PERSON / HAS NEVER / BEEN HERE / BEFORE / NEVERTHELESS / THE SITUATION / SEEMS / FAMILIAR / THE ROOM / IS FULL / OF OBJECTS / THEY ARE SPREAD / ALL OVER / IT IS PRETTY / MESSY / OBVIOUSLY / THERE IS NO ORDER / ONLY / THE FRUIT / ON THE GROUND / SEEM PLACED / AS IT WERE / ACTUALLY / EVERYTHING / PROVES TO BE / CAREFULLY / STAGED AND SET UP / NEXT TO AN ANANAS / THERE IS A LITTLE OBJECT / IT IS SO TINY / THAT IT / HARDLY EVER 
at denne tekstens bokstaver også er elementene til fem andre tekster. ${ }^{37}$ Disse blir først synlige i fragmenter, idet hver bokstav som dukker opp forblir i projeksjonen. Så øker disse fragmentene i omfang og antall mens stadig flere bokstaver dukker opp. Og så, ved slutten av denne sekvensen, blir de fem andre tekstene synlig i sin helhet, før de svinner inn til lyslinjer. Dette danner igjen overgangen til den neste sekvensen, hvor en annen lyslinje dukker opp - i form av en fluorescerende snor som utøverne, selv usynlig på den da mørke scenen, beveger gjennom rommet.

I disse eksemplene utfolder de ovennevnte teatervitenskapelige impulsene seg, som først hadde vist seg i mitt scenekunstnerisk arbeid ved å prege begynnelsen av NO MORE THEATRE, enda tydeligere. De viser seg, så å si, i scenekunstnerisk videreutviklete former. At den kombinatoriske leken med bokstavobjektene og -projeksjonene står i sammenheng med et semiotisk blikk på arbitrariteten og differensialiteten til språklige tegn er åpenbart. Likeså åpenbart er denne leken preget av en fenomenologisk oppmerksomhet på signifikantenes materialitet, særlig som bevegelig materiale i romlige og tidlige forhold. I tillegg blir dermed iterabiliteten eller siterbarheten av språklige tegn i dekonstruktivismens forstand, på en særlig måte konkret. Det kan til og med sies at den kombinatoriske leken nesten virker som en scenisk demonstrasjon av de sentrale begrepene til Jacques Derridas grammatologi. At det brukes skrift i stedet for tale, at altså utøverne ikke prater til tilskuerne, men staver forestillingens tekst foran publikumet ved bruk av bevegelige skrifttegn, kan sees i forhold til Derridas phonocentrisme-kritikk, det vil si hans kritikk av den muntlige talens prioritering overfor skriften siden Platon. Det kan også sees som en konkret iscenesettelse av måten Derrida forklarer sitt begrep différance på, særlig i lys av hans formulering av at «the play of difference, which, as Saussure reminded us, is the condition for the possibility and functioning of every sign, is in itself a silent play. ${ }^{38}$ Akkurat dette blir i den kombinatoriske leken med bokstavobjektene og -projeksjonene (ved siden av at denne leken faktisk er stille) særlig tydelig: Skrifttegnene fungerer, og stadig vekk forandrer deres funksjon, idet de flyttes gjennom forskjellige forhold til andre tegn. Med andre ord: De reitereres og vises dermed i deres iterabilitet. Den kombinatoriske leken med dem kunne så til og med selv kalles for différance. For Derrida definerer différance nettopp som «the playing movement that 'produces' [...] these differences, these effects of difference.. ${ }^{39}$ Likeså viser seg - mens bokstavobjektene eller -projeksjonene beveges, mens de flyttes gjennom forskjellige forhold til andre tegn - hva Derrida kaller for trace, espacement og archiécriture når han videre skriver om différance:

It is because of différance that the movement of signification is possible only if each so-called 'present' element, each element appearing on the scene of presence, is related to something other than itself, thereby keeping within itself the mark of the past element, and already letting itself be vitiated by the mark of its relation to the future element, this trace being related no less to what is called the future than to

\footnotetext{
GETS / NOTICED / AND TO VIEW IT / STRESSES / THE EYES / NEVERTHELESS / IT IS ALL ABOUT / HOW TO GET AT IT.

${ }^{37}$ Hver av disse tekstene består faktisk bare i to setninger, som tar utgangspunkt fra et element som spiller en rolle i denne scenen (THEATRE, PROJECTIONS, TEXT, SCREEN, WORDS) og dreier seg om hva disse elementene ikke er, men likevel giør. For bilder av denne scenen som viser tekstene, se https://www.pahn.no/publikasjoner, og http://www.avantgarden.no/bastard/170923-avdal-shinozakifieldworks-unannounced $17 /$.

${ }^{38}$ Derrida, Jacques. Margins of Philosophy. 5. Chicago: The University of Chicago Press, 1982.

${ }^{39}$ Ibid., 11.
} 
what is called the past, and constituting what is called the present by means of this very relation to what it is not [...]. An interval must separate the present from what it is not in order for the present to be itself, but this interval that constitutes it as present must, by the same token, divide the present in and of itself, thereby also dividing, along with the present, everything that is thought on the basis of the present, that is, in our metaphysical language, every being, and singularly substance or the subject. In constituting itself, in dividing itself dynamically, this interval is what might be called spacing, the becoming-space of time or the becoming-time of space (temporization). And it is this constitution of the present [...] that I propose to call archi-writing, archi-trace, or différance. ${ }^{40}$

Med blikk på den kombinatoriske leken med bokstavobjektene og -projeksjonene kan det faktisk sies at disse - som nåværende elementer på nærværets scene - særlig tydelig bærer preg av både tidligere og framtidige forhold til andre elementer. På den ene siden etterlater de, mens de flyttes henholdsvis dukker opp, konkrete spor av tidligere forhold. På den andre siden er bokstavene i disse momentene samtidig allerede $\mathrm{i}$ ferd med å inngå et nytt, framtidig forhold med andre elementer. Sånn er hvert av de forholdene som oppstår - i deres forbigående nærvær - synlig som både etterfølger og forgjenger av andre forhold. Deres nærvær er, med Derridas ord, dynamisk delt. Og intervallet som han kaller for «spacing» (espacement) tar til og med bokstavelig form mellom og rundt bokstavene: Det viser seg i de konkrete rommene mellom bokstavobjektene og projeksjonene, samt i deres forhold til rommet generelt. Intervallet viser seg, nærmere bestemt, mellom bokstavobjektenes og -projeksjonenes nåværende posisjoner og alle steder i rommet hvor de har vært før og hvor de framtidig vil kunne være. Og disse romlige forholdene og intervallene, som etterhvert blir til og forandrer seg, kan så absolutt beskrives som eksempler på en rom-blivelse av tid eller tid-blivelse av rom (om Derridas begrep kan oversettes slik).

Ikke minst kan én ting til sies, eller bedre, skrives om denne archi-skrivingen (særlig måten det bygges tekst på med de kubiske bokstavobjektene kan besktives som en slags arkitektonisk skriving eller arki-tekstur): Slik som den deler nærværet, så deler den også subjektet. Nærmere bestemt: Også tekstens subjekt deles dynamisk. For verken i distant voices, i carry on eller i unannounced fins den singulære substansen av et enkelt talende subjekt. Slik som tekstene istedenfor presenteres i form av en «silent play» med skrift, så presenteres de også i form av et samspill mellom flere utøvere. $\mathrm{Og}$ disse opptrer ikke som suveréne subjekter som styrer tekstenes utviklinger. Heller lar de seg styre av tekstenes utviklingsprinsipper: De forholder seg til tekstenes og skrivingens spilleregler - eller: reglene til «the play of difference» - som styrende faktorer. ${ }^{41}$

Det er riktignok viktig å klargjøre at verken Derridas diskurs eller andre teoretiske diskurser var direkte styrende for utviklingen av den kombinatoriske leken med skrifttegn i de nevnte arbeidene. At denne leken kan beskrives med Derridas begrep og i forhold til tilsvarende sitater betyr ikke at den faktisk var en direkte iscenesettelse av disse, eller at en direkte referanse til dem lå til grunn for denne lekens utvikling. Forskjellig fra f. eks. den direkte referansen til diskursen om Minimal Art, altså den konkrete bruken av det ovennevnte sitatet av Sol Le Witt i distant voices, er de virkningene

\footnotetext{
40 Ibid., 13.

41 Utøvernes samspill minner til og med om et spill, særlig i carry on, hvor de to utøverne som utfører tekstsekvensen plasserer bokstavene etter tur, som om hver plassering var et trekk i et sjakkaktig parti.
} 
av dekonstruktivistiske, semiotiske og fenomenologiske impulser som viser seg i denne leken heller indirekte virkninger. De er, så å si, virkninger av diskurs-sedimenter, som har, på min teatervitenskapelige løpebane, til forskjellige tider, i forskjellige sammenhenger og i forskjellige lag avleiret seg som grunnlag for mitt scenekunstnerisk utviklingsarbeid.

Å påpeke dette er særlig relevant for å vise at og presisere hvordan teatervitenskapens performative kraft kan utfolde seg på forskjellige måter i scenekunstnerisk utviklingsarbeid, nemlig både indirekte og direkte. Den kan utfolde seg idet det scenekunstneriske utviklingsarbeidet virvler opp teatervitenskapelige sedimenter som ligger til grunn for det. (I slike tilfeller virker den teatervitenskapelige diskursen altså heller indirekte som impulsgiver eller inspirasjonskilde.) Og den kan likeså utfolde seg ved at det scenekunstneriske utviklingsarbeidet graver ut konkrete funn fra slike sedimenter, i form av direkte referanser. (I slike tilfeller virker de tilsvarende diskursene altså som konkrete materialkilder.) I de nevnte arbeidene skjer begge deler - i forskjellige grader og i forbindelse med hverandre. Og som materialkilder viser seg de nevnte sedimentene i form av både tekstuelle referanser til diskurser og visuelle referanser til det disse diskursene dreier seg om. Forbindelsen mellom sitatet av Sol Le Witt (som tekstuell referanse til diskursen om Minimal Art) og bruken av kubiske objekter (som visuell referanse til Minimal Art) er ett eksempel på det. Et annet eksempel finnes i unannounced: At teksten i dette arbeidet nevner «the fruit on the ground» som «seem placed, as it were», står i sammenheng med min forskning på illusjon i samtidsteater sammen med bruken av de fruktene som i denne scenen faktisk ligger på gulvet foran teppet som teksten projiseres på. Disse fruktene er nemlig ikke ekte, men naturtroe attrapper - som det viser seg på slutten av forestillingen, idet de begynner å gjengi lyd. Bruken av disse attrappene ${ }^{42}$ er inspirert av den antikke fortellingen om konkurransen mellom malerne Zeuxis og Parrhasios. I denne konkurransen maler Zeuxis druer som ser så ekte ut at fugler prøver å spise dem, men Parrhasios vinner til slutt ved å male et teppe som så lurer Zeuxis. ${ }^{43}$ Referansen til denne fortellingen om kunstnerisk synsbedrag, kan igjen sees i forbindelse med en ytterligere diskurs, som både spiller en viktig rolle i forskningen min og som var en impulsgiver til teksten i unannounced: Jacques Lacans psykoanalytiske teori. At skinnet bedrar er et sentralt tema i denne teorien, og impulsen denne teorien har gitt teksten viser seg i dens siste passasje: Når det nevnes «a little object» der, så er det en referanse til Lacans begrep «objet petit a». Dette begrepet står i hans teori for begjærets årsak, som han også beskriver som eksistensens skinn, ${ }^{44}$ og er en grunnleggende teoretisk referanse til Postspektakuläres Theater (samt et bindeledd mellom min tilsvarende forskning og dens fortsettelse med blikk på illusjon i samtidsteater).

\footnotetext{
${ }^{42}$ Første gang jeg brukte slike frukt-attrapper, var på den vitenskapelig-kunstneriske konferansen TO DO AS IF - Realitäten der Illusion im zeitgenössischen Theater, som jeg arrangerte 2012 ved instituttet i Giessen. Fruktattrappene var da, ved siden av ekte frukt, del av bufféen for konferansedeltakerne. En banan-attrapp ble ved denne anledningen knekket, da én av deltakerne provde å skrelle den. Idéen om å bruke slike fruktattrapper også $\mathrm{i}$ unannounced oppstod forresten på grunn av at tittelen lyder nesten som ordet ananas. Her kan, selv om dette var ikke vår intensjon, absolutt sees en forbindelse med Derridas forandring av ordet différence til begrepet différance, som - ved å forandre ordet slik at forskjellen bare viser seg i stavemåten, men ikke kan høres i talen - skal framheve den skriftlige dimensjonen.

${ }_{43}^{4}$ Jf. bok 35, avsnitt 36 i Pliny. Natural History, Volume IX, Books 33-35. Cambridge MA: Harvard University Press, 1952.

${ }^{44}$ Jf. Lacan, Jacques. Le Séminaire. Livre XX. Encore, 1972-1973. Paris: Seuil. 1975. For et overblikk over begrepets utvikling i Lacans teori jf. Evans, Dylan. Wörterbuch der Lacanschen Psychoanalyse. 205-206. Wien: Turia und Kant, 2002.
} 
Men også for disse mer direkte teoretiske referansene gjelder det at de ikke var styrende for tekstens utvikling. Det betyr samtidig at man ikke må kjenne de tilsvarende teoriene for å kunne forstå eller få tilgang til teksten (selv om en slik kjennskap kan gjøre en forskjell med hensyn til hvordan man tolker den). Disse referansene er altså verken det som skal iscenesettes og eksemplifiseres, eller nøkler som trengs for tekstens forståelse. Likevel kan de selvfølgelig utløse eller bidra til erfaringer som likner eller til og med tilsvarer det som beskrives av de diskursene som det refereres til (slik som frukt-attrappene i unannounced, før de gjengir lyd, faktisk lurer tilskuerne $\mathrm{i}$ form av et synsbedrag). Men det som først og fremst skal vises her er at disse referansene til den teatervitenskapelige diskursen fungerer, som sagt ovenfor, som impulsgiver, inspirasjons- og til og med materialkilde for scenekunstnerisk arbeid. Og som denne artikkelen forhåpentligvis også demonstrerer, kan de da i tillegg igjen fungere som referansepunkter for dette arbeidets teoretiske refleksjon.

Ikke minst - for å komme tilbake til interessen for en kritisk refleksjon over stereotypiske oppfatninger - kan det nok også sies at den måten å arbeide med tekst på som de nevnte diskursene har inspirert, skiller seg fra stereotypiske oppfatninger om tekstens rolle i scenekunst. For selv der hvor scenekunsten er preget av postdramatiske estetikker, prioriteres som regel det talte ord og utøvernes stemmer som tekstformidlende virkemidler. Dette betyr riktignok ikke at disse virkemidlene ikke selv kan brukes for å utfordre disse stereotypiene, som det nedenfor skal eksemplifiseres med henblikk på Malmborgs arbeid b o n e $r$. Dette arbeidet viser dessuten hvordan teatervitenskapens performative kraft kan utfolde seg på bakgrunn av direkte referanser til den teatervitenskapelige diskursen. Samtidig er b o n e r et godt eksempel på at dette ikke må bety at de tilsvarende arbeidene derfor var kun tilgjengelig for de som kjente til denne diskursen. Men før det gås inn på dette eksempelet vil først Mette Ingvartsens arbeid, 69 positions, drøftes.

\section{Hvordan gjøre koreografi med historiografi}

A drøfte Mette Ingvartsens 69 positions i forhold til historiografi - det første av de tre tematiske fokusområdene til konferansen i Bergen - er nærliggende. Det kunne til og med sies at det ikke var nødvendig å se arbeidet for å komme på denne idéen. ${ }^{45}$ For å vite at 69 positions har noe med historiografi å gjøre, ville det faktisk holde å bare lese informasjonen om serien The Red Pieces, som arbeidet er del av, på Ingvartsens hjemmeside. For der står det at denne serien «inscribes itself into a history of human performance with a focus on nudity, sexuality and how the body historically has been a site for political struggles. $\rangle^{46}$

Denne formuleringen - ved å ikke skrive at serien automatisk var del av denne historien, men at den istedenfor skriver seg inn i den - gjør det tydelig at serien faktisk er et historiografisk prosjekt. Samtidig impliserer den - utover spørsmålet om seriens forhold til denne historien - en generell bevissthet om erkjennelsen som ligger til grunn for historiografi-begrepet, nemlig at historien ikke bare fins som noe som er objektiv gitt, men at den alltid skrives fra subjektive posisjoner og perspektiver. Hver måte å forske på historien (eller heller på fortiden) betyr derfor å skrive en

\footnotetext{
${ }^{45}$ Jeg har sett 69 positions på PACT Zollverein Essen på 03.10.2014 og ved Oktoberdansfestival 2014 i Bergen.

${ }^{46}$ Ingvartsen, «Biography.»
} 
særskilt framstilling av den, altså nettopp en historie, som nødvendigvis inkluderer, prioriterer og framhever noen aspekter, mens den nedprioriterer, tier stille om og utelukker andre. ${ }^{47}$

Denne generelle erkjennelsen er - som konferansens fokus på historiografi-begrepet viser - også av sentral relevans for den teatervitenskapelige diskursen og fagets forskning på teater i fortiden. Og siden Ingvartsens serie ikke bare selv består i former for human performance, men også tematiserer tidligere former for det, særlig fordi 69 positions fokuserer på «experimental performances of the 60 's», ${ }^{48}$ kan det spesifiseres at det dreier seg i dette tilfellet om teaterhenholdsvis scenekunsthistoriografi. Med andre ord: Allerede måten 69 positions beskrives på i den siterte parateksten gir god grunn til å granske arbeidet som et eksempel på hvordan gjøre scenekunst med historiografi - eller nærmere bestemt: hvordan gjøre koreografi med teaterhenholdsvis scenekunsthistoriografi.

69 positions begynner med at publikumet kommer inn i et slags rom-i-rom-installasjon, nærmere bestemt et galleri-aktig område i et større rom, definert av et hvitt gulv og en metallisk gittervegg. Sistnevnte bærer forskjellige dokumentariske materialer, henholdsvis tekster, bøker og bilder (presentert på hvite tavler), samt flatskjermer som viser videoer. På Ingvartsens hjemmeside betegnes denne installasjonen som et «archive of sexual performances», ${ }^{49}$ og faktisk minner dette arkivet om kjennemerker til forskjellige former for arkiver, særlig til biblioteker og museer.

Allerede utformingen av rommet er dermed inspirert av historiografiske aspekter, siden det er nettopp arkiver som danner hovedgrunnlaget til historiografisk arbeid. Der lagres dokumentene, objektene og artefaktene dette arbeidet er avhengig av. Og før det gjøres et utvalg av hvilket arkivmateriale historien skal skrives på basis av, har det allerede skjedd en sondering av hva som overhodet skal arkiveres eller ikke, hva som skal oppbevares i arkivene for å representere fortiden, og hva som skal ikke oppbevares og kan (eller til og med skal) glemmes. I denne forstand er arkivet altså ikke bare grunnlaget for historiografisk arbeid, men fungerer også på basis av de samme prinsippene, nemlig seleksjon, inklusjon og eksklusjon. Følgelig er det ikke bare et sted for å lagre fortidens spor, men også et maktapparat som kan la disse forsvinne.

Riktignok har - i sammenheng med populariteten som arkivbegrepet har oppnådd i bl.a. kunstvitenskapelige og kunstneriske diskurser siden 1990-tallet - også en annen forståelse av arkivet blitt godt likt, nemlig dets beskrivelse som heterotopi i Michel Foucaults L'Archéologie du savoir fra 1969. At dette årstallet stemmer overens med tallet i tittelen 69 positions er nok mest sannsynligvis en morsom tilfeldighet. Men i lys av at 69 positions skal «explore unresolved issues about sexuality in contemporary practices today ${ }^{50}$, som impliserer en kritisk holdning overfor de historiografiene som har skapt eller i det minste ikke løst disse problemene, er det ikke usannsynlig

\footnotetext{
${ }^{47}$ I den forrige utgaven av Teatervitenskapelige studier viser f. eks. Ellen Karoline Gjervan hvordan eksistensen av pantomimesjangeren i Norge mellom $1750 \mathrm{og} 1850 \mathrm{har}$, i sammenheng med den norske nasjonsbyggingstradisjonen, blitt marginalisert i de eksisterende hovedverkene om norsk teaterhistorie (jf. Gjervan, Ellen Karoline. «Komiske og historiske pantomimer rundt 1800 - I Europa, Norge og i norske teaterhistorier». Teatervitenskapelige studier 3 (2019): 17-26. https://boap.uib.no/index.php/tvs/article/view/2925/2890).

48 Ingvartsen, Mette. «69 positions,» Mette Ingvartsen. 2020. https://www.metteingvartsen.net/performance/69-positions/

${ }^{49}$ Ingvartsen, «69 positions.»

${ }^{50}$ Ibid.
} 
at heterotopi-begrepet er av interesse for Ingvartsen. For hva Foucault beskriver med dette begrepet er, slik som professor i litteraturvitenskap Knut Ove Eliassen sammenfatter det, to ting: For det første er det «en subversiv måte å bruke de historiske arkivene på» ved å finne fram materialer som tillater «andre former for fremstillinger av de historiske prosessene» og «setter etablerte sannheter på spill» ${ }^{51}$. For det andre, er det et blikk på arkivet som «et særlig privilegert sted for erfaringer», nærmere bestemt for «en estetisk erfaring av historien», som også innebærer «en eksplisitt fysisk erfaring» av arkivets materialer og «historiens fremmedhet». ${ }^{52}$

At Ingvartsens arbeider forholder seg generelt på en kritisk og subversiv måte til historien om scenekunstens fortid, slik som den vanligvis fortelles, samt at de til og med anvender både sentrale topoi og konkrete relikter, sporer og etterlatenskaper fra denne fortiden ved å kritisk vende de mot seg selv, har jeg beskrevet tidligere. ${ }^{53}$ I denne sammenhengen har jeg, med hensyn til både 69 positions og Ingvartsens tidligere arbeider Manual Focus, 50/50 og to come (som hun selv tematiserer i 69 positions - mer om det nedenfor), vist at det er særlig topoi som nakenhet, møtet fra ansikt til ansikt og deltakelse, samt antakelsen at disse garanterte mellommenneskelig umiddelbarhet, som Ingvartsen kritisk (an-)vender mot dem selv. Det kan altså vurderes som ganske sikkert at det som hun er interessert i med henblikk på arkiver tilsvarer det første aspektet av heterotopi-begrepet som Eliassen beskriver. Og angående det andre aspektet kan det til og med sies at det sceniske arkivet 69 positions foregår i er faktisk akkurat det: et sted for estetiske og fysiske erfaringer av de arkiverte materialene og av fremmedheten til den historien som Ingvartsen (be)skriver og framfører. For Ingvartsen agerer i dette arkivet gjennomgående blant publikum, i tett kroppslig nærhet og ofte med kontakt, samt naken etter den første halve timen. Og i løpet av den til sammen ca. to timer lange forestillingen oppfordrer hun tilskuerne gang på gang til å delta i gjennomføringen av forskjellige aksjoner. Så animerer hun dem bl.a. til å etterligne, sammen med henne, deler av Carolee Schneemanns koreografi Meat Joy fra 1964 og Richard Schechners performance Dionysus in 69 fra 1968 (i dette tilfellet er overensstemmelse mellom tallene i titlene ikke tilfeldig). Senere oppfordrer hun hele publikumet å forestille seg å være naken som henne - og involverer flere tilskuere kroppslig i framstillingen av posisjoner til en gruppesex-situasjon med sadomasokistiske elementer, som hun samtidig beskriver og demonstrerer. Ytterligere former for publikumsdeltakelse er så at fem tilskuere inviteres til å framføre orgasmekorsekvensen fra Ingvartsens tidligere arbeid to come (idet disse tilskuerne hører porno «orgasmen» via hodetelefoner og gjengir dem med stemmene sine), at hun ber én tilskuer om å surre og kneble henne med tape (og å befri henne igjen etter en liten stund), og at hun oppfordrer hele publikum om å lytte med lukkete øyne til hennes fortelling om en seksuell praksis kalt elektrostimulasjon. ${ }^{54} \AA$ si, med Eliassens ord, at den «estetiske erfaringen av historien» som tilskuerne i 69 positions gjør er «en eksplisitt fysisk erfaring» - særlig av det som konfronterer dem som den fortalte og framførte «historiens fremmedhet» - er nok en ganske treffende beskrivelse av det som skjer på denne turen gjennom Ingvartsens «archive of sexual performances».

\footnotetext{
${ }^{51}$ Eliassen, Knut Ove. «Arkivet og heterotopien». Kunstjournalen B-post, nr. 1 (2011). https://bpost.no/no/11/eliassen.html

52 Ibid.

${ }^{53}$ Jf. Eiermann, «Pleasures to come»; Eiermann, «A postspectacular perspective on 〈relational aesthetics〉 and audience participation»; Eiermann, Postspektakuläres Theater (Bielefeld: Transcript, 2009).

54 Angående deltakelsesaspektet i 69 positions se Eiermann, «A postspectacular perspective on srelational aesthetics $>$ and audience participation».
} 
Men det historiografiske perspektivet og den tilsvarende framgangsmåten som koreografien baserer seg på - eller nærmere bestemt: som den gjøres med - viser seg ikke bare i forhold til arkivog heterotopibegrep. Det blir også - selv om Ingvartsen ikke snakker eksplisitt om historiografi tydelig i måten hun introduserer prosjektet på like ved forestillingens begynnelse. For det som hun gjør aller først, når tilskuerne kommer inn i arkivet hennes, er å hilse dem velkommen og å forklare de materialene som er utstilt i arkivet. I denne sammenhengen henviser hun også direkte til hennes historiografiske framgangsmåte, samt til det tilsvarende seleksjonskriteriet: Materialene ble, som hun forklarer, utvalgt fordi de framstiller en eksplisitt relasjon mellom seksualitet og det offentlige, henholdsvis fordi de tematiserer seksualitetens rolle i samfunnet og som politisk faktor. Og rett etterpå opplyser hun også om den historiske horisonten 69 positions refererer seg til: Turen, som hun kaller forestillingen for, begynner på 1960-tallet, lar hun publikum få vite.

Tilsvarende er forestillingens første del en gjennomgang gjennom dette tiåret langs de dokumentasjonsmaterialene som Ingvartsen har samlet i sitt arkiv, og som er relatert til forskjellige kunstneriske arbeider fra denne tiden. Det første dokumentet som Ingvartsen leser opp for publikum, er en utskrift av en e-postkommunikasjon mellom henne og Carolee Schneemann. Den dreier seg om Ingvartsens forespørsel om det var mulig å oppføre Schneemanns arbeid Meat Joy igjen, med de samme, nå femti år eldre utøverne. Ytterligere arbeider som Ingvartsen så forholder seg til, ved siden av Schechners allerede nevnte performance Dionysus in 69, er Anne Halprins koreografier Parades and Changes fra 1965 og The Blank Placard Dance fra 1967, filmen Flaming Creatures av Jack Smith fra 1963, og senere, da i forbindelse med referansen til hennes eget arbeid 50/50, Yvonne Rainers No Manifesto fra 1965.

Men som allerede sagt: Ingvartsen refererer seg til disse arbeidene ikke bare ved å lese opp eller vise de tilsvarende dokumentasjonsmaterialene. Flere av de nevnte arbeidene presenteres også i form av videodokumentasjon som vises på arkivets flatskjermer. Og stort sett består Ingvartsens måte å referere til sine eksempler på, $\mathrm{i} a ̊$ muntlig beskrive og fortelle om dem eller etterligne aksjoner fra dem. (Det sistnevnte skjer, som sagt, flere ganger også ved å involvere tilskuere.) Ofte gjør hun begge deler samtidig, for eksempel når hun framfører en sekvens fra 50/50. Hennes «archive of sexual performances» er altså et arkiv som rommer ikke bare dokumentasjoner om og av slike performancer. Det rommer også deres faktiske gjennomføringer - både idet aksjoner fra andre performancer etterlignes eller gjennomføres på nytt, og da 69 positions selvfølgelig selv er en slik «sexual performance».

Med 69 positions skriver Ingvartsen altså historien om «human performance with a focus on nudity, sexuality and how the body historically has been a site for political struggles $»^{55}$, i første omgang, det vil si i forestillingens første del, med utgangspunkt i 1960-tallet. Og med blikk på dette tiåret forholder hun seg til et spesifikt utvalg av særskilte eksempler. Enda mer spesifikk blir hennes utvalg av eksempler i forestillingens andre del, når hun skriver denne historien videre med fokus på sine egne arbeider fra 2000-tallet. Nærmere bestemt er det de allerede nevnte koreografiene 50/50 og to come, samt Manual Focus (tre koreografier som i seg selv er et utvalg av hennes arbeider).

\footnotetext{
${ }^{55}$ Ingvartsen, «Biography.»
} 
Fokuset forsnevres altså ganske håndgripelig, og samtidig viser det seg at Ingvartsens historiografi ikke er en fortelling med gjennomgående kontinuitet. I stedet forteller hun historien (sin) om sexual performances ved å utelate en ganske stor del av fortiden siden 1960-tallet. Det fins en glippe i hennes historiografi, som omfatter et tidsspenn på fire tiår. Eller med andre ord: Ingvartsens historiografi hopper, så å si direkte fra 1960-tallet til 2000-tallet, uten å fortelle noe om tiden imellom. At hun da i tillegg, vedrørende 2000-tallet, kun forteller om sine egne arbeider, kunne egentlig være en grunn for å si at hun faktisk heller skriver en historie om sin cuvre enn en alminnelig historie om sexual performances. Likeså kan det sies at hennes referanser til eksempler fra 1960tallet først og fremst viser hvilke tidligere arbeider som har vært og er av relevans for hennes arbeider, inklusive 69 positions. Riktignok presenterer hun sine arbeider samtidig både som eksempler på og refleksjoner over historien om sexual performances. Og at hennes måte å skrive denne historien på og å skrive sine arbeider inn i den på, er på en så tydelig måte selektiv og subjektiv, kan faktisk beskrives akkurat som grunnen til at hennes historiefortelling blir synlig som historiografi. Istedenfor å prøve å skjule det ved å suggerere historiens fullstendighet, viser Ingvartsens historiografi seg som historiografi. På denne måten viser det seg likeså at denne historiografien ikke bare skriver 69 positions og de andre arbeidene fra serien The Red Pieces inn i historien om sexual performances, men at 69 positions samtidig selv skriver Ingvartsens tidligere arbeider inn i denne historien.

69 positions kan dermed på den ene siden beskrives som en koreografisk historiografi. Den skriver (sin) historie ikke bare med skrift og forteller den heller ikke bare med språk. Den framstiller denne historien også i form av aksjoner, og arrangerer de samlete arkivmaterialene stort sett i form av en bevegelses-skrift, altså på en koreo-grafisk måte. På den andre siden, siden historiografiske prinsipper og framgangsmåter ligger til grunn for det - altså seleksjon og arkivering av dokumentarisk materiale på basis av et særskilt kriterium, samt fortelling om og demonstrasjon av en særskilt historie på basis av disse utvalgte materialene - kan 69 positions samtidig beskrives som en historiografisk koreografi, eller som historio-koreografi.

Det kunne altså til og med sies at 69 positions, slik som nitallet i tittelen er en snudd versjon av sekstallet, liksom snues det vanlige forholdet mellom scenekunst og historiografi. Selvfølgelig kan 69 positions, som koreografi, selv være gjenstand for historiografi (og det var ikke overraskende om den ville bli det i Ingvartsens videre arbeid). Men likeså er historiografi, nærmere bestemt et historiografisk perspektiv og tilsvarende framgangsmåter, også gjenstand for 69 positions som koreografi. Det historiografiske perspektivet og de tilsvarende framgangsmåtene anvendes ikke bare med hensyn til et utvalg av materiale, dens framstillingsformer og forestillingens dramaturgi. De tematiseres også, idet Ingvartsen eksplisitt forklarer hvordan hun har valgt ut forestillingens referanser. 69 positions er dermed, i forhold til teater- og scenekunsthistoriografi, et eksempel til på hvordan den performative kraften til teatervitenskap som diskurs kan utfolde seg i scenekunstneriske arbeider - kort sagt: et eksempel på hvordan gjøre koreografi med historiografi. 


\section{Hvordan gjøre teater med teori}

A si at bo on e rav Iggy Malmborg ${ }^{56}$, i sammenlikning med de fleste eksemplene som ellers er drøftet i denne artikkelen (bortsett fra NO MORE THEATRE), var det arbeidet som mest tilsvarte teater i en klassisk forstand, ville faktisk høres ganske rart ut. Med henblikk på arbeidets romlige aspekter kan det riktignok gi en viss mening. For $b$ o n e r framføres i teaterrom med et absolutt klassisk skille mellom sal og scene - slik som også Malmborgs andre prosjekter etter $b$ o n e $r$, altså 99 Words for Void (i samarbeid med Maike Lond), Physics and Phantasma og Things in my mouth (i samarbeid med Rea Lest). I alle disse arbeidene snakker henholdsvis Malmborg, Lond og Lest frontalt til publikum. De fleste av disse arbeidene involverer også noen relativt moderate former for publikumsdeltakelse. I $b$ o n e $r$ finner tilskuerne for eksempel notatblokker på plassene sine, og Malmborg ber dem om å skrive ned mulige utgangspunkter for nye kunstneriske prosjekter i løpet av forestillingen, for å så kaste arkene opp på scenen til ham. I 99 Words for Void oppfordrer Malmborg og Lond publikumet til å fungere som menneskelig mikrofon ved å korisk gjenta en tekst de dikterer. Og i Physics og Phantasma består en sekvens i at det utdeles ølflasker til publikum, som tilskuerne gir videre gjennom rekkene. Men i alle arbeidene overskrider verken utøvere eller tilskuere grensen mellom sal og scene - bortsett fra i Things in my mouth, hvor Malmborg en gang setter seg mellom tilskuerne. Til gjengjeld begynner akkurat dette arbeidet med den eksplisitte kunngjøringen at forestillingen skal ikke inneholde publikumsdeltakelse, som Malmborg meddeler publikummet med et diskret smil. I denne referansen til diskursen om deltakelse viser det seg samtidig enda et kjennetegn som disse arbeidene har til felles, i tillegg til skillet mellom scene og sal. Nærmere bestemt det kjennetegnet som skal stå $\mathrm{i}$ fokus her, nemlig at alle disse arbeidene refererer seg intensivt til teatervitenskapelig teori, samt til teoretiske diskurser med teatervitenskapelig relevans. De kan derfor generelt omtales som eksempler på hvordan gjøre teater med teori - eksempler som her skal representeres av boner.

Som tittelen antyder, har også $b$ o n e $r$ noe med seksualitet å gjøre. Riktignok dreier det seg i dette tilfellet, forskjellig fra 69 positions, ikke om et historiografisk blikk på «sexual performances». I første rekke refererer tittelen seg til faktumet at Malmborg gir seg selv fire oppgaver i løpet av denne soloforestillingen (hver av dem gjennomfører han to ganger, først uten og så med hjelpemidler), nemlig å finne på nye kunstneriske prosjekter, å gråte, å rødme, og å få en ereksjon. ${ }^{57}$ Men det som egentlig er avgjørende i forhold til Ingvartsens referanse til historiografi, er at Malmborgs $b$ o n e $r$ står i stedet $i$ sammenheng med forskjellige teorier som, på ulike måter, setter spørsmålstegn ved akkurat den stereotypiske oppfatningen som en «bonen», under patriarkalske forhold, tradisjonelt står for: at det mannlige subjektet er $\mathrm{i}$ besittelse av makten, og at det er suverent overfor andre mennesker, andre arter, samt overfor ting.

\footnotetext{
${ }^{56} \mathrm{Jeg}$ har sett $b$ o n e $r$ på 05.09.2015 ved Bastard-festival i Trondheim og på 02.03.2016 ved Oslo Internasjonale Teaterfestival.

${ }^{57}$ Hjelpemiddel for å gråte er tigerbalsam, som Malmborg gnir under øynene. Hjelpemiddel for å rødme er ballonger som han blåser opp, og hjelpemiddel for å få en ereksjon er en viagrapille. Den første oppgaven, altså oppgaven med å finne på nye kunstneriske prosjekter, gjennomføres faktisk begge ganger med hjelpemidler: Først er disse hjelpemidlene det som står på de arkene som tilskuerne til da har kastet på scenen. Så gjennomføres oppgaven igjen ved at Malmborg, som det uttrykkes i forestillingen, kombineres med kunnskap - noe som betyr at det han da «finner på» er allerede eksisterende og mer eller mindre kjente kunstneriske arbeider.
} 
Som tilskuer får man vite dette når Malmborg, etter én time, forklarer hva som var utgangspunktet for arbeidets utvikling med følgende ord:

When I started to work on this piece, from... the very beginning, the idea, or what I wanted to do was to find strategies of how to turn males on stage into objects, instead... ehm... males that, of course... or... like, the traditional male would of course be the one on stage that is a strong subject, rather with a strong willpower, who makes choices and shapes situations, right? And then, they guide you through a narrative, somehow. How to... how to turn them, or how to turn us, actually, how to turn us into objects, which will mean to look at us rather as we're looking at objects... ${ }^{58}$

Malmborg fortsetter denne teksten ved å fortelle om et filosofisk perspektiv. Som han sier har han støtt på det i forbindelse med forskningen for prosjektet, og så utdyper han dette perspektivet og hans overveielser på basis av det i en lengre monolog.

Det han her refererer til (han går ikke nærmere inn på kilder) er faktisk aktør-nettverk-teorien. Og når han gir et eksempel på en forbindelse mellom menneskelige og ikke-menneskelige aktører, så gjengir han akkurat det som Bruno Latour, én av denne teoriens mest kjente representanter, beskriver som menneske-pistol-aktant. ${ }^{59}$ I Malmborgs ord lyder denne beskrivelsen slik:

Like... a good example would be... ehm... that classical dilemma of, you know: Do guns kill people? Or do people kill people? One could say that actually it's neither nor, because the gun... the gun is one singular agent with certain properties and a certain agency. And the human being is another singular agent with certain properties and certain agency. And when they meet... ffffp... then they form a new, third agent, which will be the armed person, that has a new agency, or new properties. Might be dangerous... ${ }^{60}$

Aktør-nettverk-teorien - samt konkrete tekster om det - brukes her altså som grunnlag for og delvis som faktisk materiale til Malmborg sin tekst. Og selv om aktør-nettverk-teorien ikke er en teatervitenskapelig teori, så refererer særlig den aktuelle teatervitenskapelige diskursen ganske intensivt til den, ikke minst $\mathrm{i}$ videreføringen av diskusjonen om begrepet performativitet $\mathrm{i}$ form av diskusjonen om begrepet agency.

\footnotetext{
${ }^{58}$ Malmborg, Iggy. b o n e $r$. Forestilling. 12.11.2014. Tekst transkribert på basis av denne forestillingens videodokumentasjon.

59 Jf. Latour, Bruno. «On Technical Mediation - Philosophy, Sociology, Genealogy». Common Knowledge 3, nr. 2 (1994): 29-64. Latour argumenterer, i forhold til de to motstridende slogans: «Guns kill people» og «People kill people; not guns» (ibid., 30-31), at kombinasjonen mellom et menneske og en pistol skaper en form for aktør som hverken mennesket eller pistolen er i seg selv (jf. ibid., 30-34), nærmere bestemt en «hybrid actor» (ibid., 33). I denne sammenhengen påpeker han at «[w]e must learn to attribute - redistribute - actions to many more agents» enn begge slogan går ut fra, siden «[a]gents can be human or (like the gun) nonhuman, and each can have goals (or functions, as engineers prefer to say)» (ibid.). At han velger begrepet «aktant» for å betegne den hybride (ikke bare menneskelige) aktøren, som menneske og pistol danner sammen, begrunner han sånn: «Since the word agent in the case of nonhumans is uncommon, a better term is actant» (ibid.).

${ }^{60}$ Malmborg, b o ner.
} 
Allerede med blikk på denne referansen kan det altså konstateres at Malmborg gjør teater med teori. Men siden han taler i denne sammenhengen, kunne det også påstås en gang til - slik som med henblikk på forholdet mellom scene og sal, og $\mathrm{i}$ lys av at jeg ovenfor hadde betegnet talen og utøverens stemme som de stereotypiske virkemidlene for å formidle tekst i scenekunst - at han gjør det på en ganske klassisk måte. Men, som også allerede nevnt, er akkurat $b$ o n e r et eksempel på hvordan tale og stemme kan brukes for å utfordre deres stereotypiske anvendelse. Og måten Malmborg uttaler seg på om sin interesse i å forvandle mannlige subjekter til objekter er et første indisium for det. For i denne uttalelsen ligger ikke bare en referanse til aktør-nettverk-teorien. I tillegg, særlig fordi det står en boner i arbeidets sentrum, innebærer den også en referanse til Derridas teori. Nærmere bestemt er det en referanse til Derridas kritikk av det han kaller for phallogocentrisme (som phonocentrisme er, i hans forstand, en del av), altså den privilegerte stillingen til det mannlige subjektet og stemmen, eller: den privilegerte stillingen til det talende, mannlige subjektet.

Akkurat denne stillingen setter Malmborg i b o n e $r$ bokstavelig talt på spill - eller: i denne stillingen setter han seg som et talende mannlige subjekt på spill. For selv om han tar, i forskjellige sekvenser av forestillingen, ordet selv, så beholder han det ikke. Han gir også ordet, eller avgir det, til andre aktører - riktignok ikke andre menneskelige aktører, men andre ikke-menneskelige aktører, kort sagt: ting. Faktisk (av)gir han ikke bare ordet til disse, men til og med stemmen sin. Og dette er igjen - allerede før han forteller om menneske-pistol-aktanten - en referanse til aktør-nettverkteorien, i særdeleshet til Latours beskrivelse av «tingenes parlament» (parlement des choses). ${ }^{61}$ For poenget med denne beskrivelsen er, som begrepet parlament tilsier, akkurat det: å gi tingene, som vanligvis forblir tause, ordet. Nærmere bestemt er poenget å realisere en politisk økologi ved å samle et kollektiv av menneskelige og ikke-menneskelige aktører $i$ et parlament hvor det å tale ikke lenger er kun en menneskelig kompetanse. ${ }^{62}$ Og tingene gis i dette parlamentet ikke bare ordet, men også «stemmeapparaten», som gjør det mulig for dem å delta i menneskenes diskusjoner. ${ }^{63}$

De ikke-menneskelige aktørene - eller, med Latours begrep, aktantene - som Malmborg gir ordet og stemmen sin til, er i første rekke tre høyttalere (som samtidig fungerer som «stemmeapparater»): to fast installerte høyttalere på stativer, plassert på venstre og høyre side av scenen, samt én liten kabelløs høyttaler, som Malmborg frakter rundt med seg på scenen. Etter en kort introduksjon, som Malmborg gir selv i forestillingens begynnelse, introduserer disse høyttalerne seg selv, ved å gjengi Malmborgs stemme. Den lille kabelløse høyttaleren taler først og sier:

I am a wireless loudspeaker. My function is to mediate sounds that are provided by a sound source. In this case, it is a computer. The computer is controlled by Maike Lond. I mediate specific sounds from a sound library. Tonight, I'm not only the mediator of sound. I'm also a mouth. As objects have such a hard time to speak, I will help them. ${ }^{64}$

Det er altså ikke bare høyttalerne som skal få ordet og stemmen, men også flere objekter. Men før disse får tale, presenterer først de to andre høyttalerne seg. Den ene beskriver seg som forteller,

\footnotetext{
${ }^{61}$ Jf. Latour, Bruno. Das Parlament der Dinge. Frankfurt am Main: Suhrkamp, 2010.

${ }^{62}$ Jf. ibid., her særlig $92 \& 96$.

${ }^{63}$ Jf. ibid., 98.

${ }^{64}$ Malmborg, b o n e $r$. Transkribert på basis av videodokumentasjonen til forestillingen.
} 
som skal kunngjøre hvert nytt skritt i forestillingen med en ringelyd, samt av og til angi en overskrift for og betingelsene for det som skal skje på scenen. Den andre presenterer seg som underholder, som skal spille av musikk når forestillingen blir litt kjedelig eller når det trengs en spesiell atmosfære.

De øvrige objektene som da, etter høyttalernes introduksjon, skal få snakke ved hjelp av den kabelløse høyttaleren, er for eksempel et bord, en lyskaster, gulvet, en kabel, samt flere andre ting, og alle disse objektene snakker om sin «most valued property». De forteller om hva slags funksjoner de har, hva slags aksjoner de gjør mulig, og hva de er nyttige for, særlig med henblikk på deres funksjon i forestillingen - samt at de ville vært søppel hvis de ikke hadde disse nyttige funksjonene lenger. Og i denne sammenhengen tematiserer de seg også som elementer av et nettverk, som bare i samspill med hverandre gjør forestillingen mulig.

Referansen til aktør-nettverk-teorien kan altså allerede i forestillingens begynnelse oppdages ved flere anledninger. Men samtidig er det allerede da ikke den eneste teorien som dette nettverket mellom Malmborg som menneskelig aktør og objektene som ikke-menneskelige aktører bruker for å gjøre teater. I tillegg gjør dette nettverket, idet det som objektene tilsynelatende snakker om faktisk er deres bruksverdi, teater også med marxistisk teori. Nærmere bestemt gjør de det til og med helt konkret med Karl Marx sin teoretiske overveielse over hva objekter (henholdsvis varer) ville si hvis de kunne tale. Ifølge Marx ville de si at deres bruksverdi interesserer vel menneskene, men at denne verdien ikke tilkommer dem som ting. ${ }^{65} \mathrm{I}$ b o n e $r$ sier de noe liknende, men omvendt, nemlig hva den bruksverdien deres er som menneskene er interesserte i - og hva de, som ting, ville bli for menneskene hvis de mistet denne verdien: søppel.

Det er altså allerede i forestillingens begynnelse et nettverk av to teorier, aktør-nettverk-teori og marxistisk økonomisk teori, som brukes for å gjøre teater. Dette blir enda tydeligere i en dialog, faktisk en diskusjon mellom de to fast installerte høyttalerne, som dreier seg om spørsmålet om de overhodet har agency, eller om det egentlig er Malmborg som faktisk er den eneste aktøren i forestillingen. I løpet av denne diskusjonen drøftes riktignok også spørsmålene hva Malmborg (høyttalerne kaller han, med sin stemme, for Iggy) sin «most valued property» som kunstner er, om kunstmarkedet definerer en kunstners verdi og derfor har en agency, og om en kunstner selv er en vare. Én av høyttalerne spør: «So, you're bringing some kind of old school marxism into this discussion?» ${ }^{66}$. Og markedet betegnes i denne sammenhengen som nettverk. Høyttalernes diskusjon, som også diskuterer seg selv ved å spørre om den egentlig er en diskusjon, slutter endelig ved å stille spørsmålet om ikke Malmborg selv er et objekt, som bare skiller seg fra ikkemenneskelige aktører fordi det lever - et spørsmål som underholder-høyttaleren besvarer med å spille av musikk.

Både aktør-nettverk-teori og marxistisk økonomisk teori brukes her altså ganske eksplisitt - den første idet dens sentrale begrep agency brukes, den andre idet den blir nevnt som «old school marxism» - og i tett forbindelse med hverandre. Og det talende mannlige subjekt som Derridas phallogocentrisme-kritikk gjelder, står særlig i denne forbindelsen på spill. For høyttalerdiskusjonen forvandler dette subjektet til et objekt - ikke bare ved å betegne Malmborg som objekt, men også ved å gjøre han faktisk til et objekt for diskusjonen. Riktignok er ikke dermed alle teorier nevnt

${ }^{65}$ Jf. Marx, Karl. Das Kapital. Erster Band. Marx/Engels: Werke, Band 23. Berlin: Dietz, 1972, 97.

${ }^{66}$ Malmborg, b o n e r. Transkribert på basis av videodokumentasjonen av forestillingen. 
som det gjøres teater med i $b$ o $n$ e $r$. En fjerde teori er Lacans psykoanalytiske teori, nærmere bestemt hans teori om stemmen som objekt (som partialobjekt) ${ }^{67}$, og enda nærmere bestemt Mladen Dolars og Slavoj Žižeks videreføring og videreutvikling av denne teorien til en teori om stemmen som kroppsløst organ. ${ }^{68}$

I teori-nettverket som brukes i b o n e r er teorien om stemmen som kroppsløst organ for det første virksom i at Malmborgs stemme atskilles fra kroppen hans. Han gir stemmen sin bort til objektene, og selv om stemmen på denne måten blir midlertidig knyttet til de enkelte objektene, er den i prinsippet selv underveis som objekt, henholdsvis som kroppsløst organ. For det andre er denne teorien også særlig virksom - for den opptrer da solo - når rommet blir helt mørk og stemmen blir hørlig alene. I denne scenen er den faktisk ikke knyttet til noe, og slik tematiserer den seg også. Den introduserer seg ved å si «hello, I am the voice», og så nevner den bl.a. at den var «not an organic part of the human body» og «not simply a medium to express subjectivity», men «rather a parasite». ${ }^{69}$ Teorien om stemmen som objekt eller kroppsløst organ blir dermed dobbelt hørlig både eksemplifisert i form av den kroppsløse stemmen selv, og i form av begrepene som brukes i det denne stemmen sier. Samtidig viser det seg i denne scenen også en forbindelse mellom $b$ o n e $r$ og et av Malmborgs andre arbeider, nemlig Things in my mouth. I dette arbeidet spiller stemmen som kroppsløst organ, slik som den tematiseres i $b$ o n e r, også en rolle, nærmere bestemt hovedrollen. Særlig beskrivelsen av stemmen som en parasitt dukker i denne sammenhengen opp igjen, samt tekstuelle referanser til Dolars diskurs.

Men kroppsløse organer fins i Malmborgs arbeider ikke bare i form av stemmer. Med et avsluttende blikk på $b$ o n e $r$ kan det sies at akkurat den kroppsdelen som tittelen fokuserer på også blir til et slags kroppsløst organ i dette arbeidet. Malmborg atskiller ikke på samme måte kjønnsorganet sitt fra kroppen, som han gjorde med stemmen. Men på grunn av måten det fokuseres på denne delen av kroppen, når Malmborg trekker ned buksen sin og prøver seg på oppgaven med å få en ereksjon, skiller den seg på et vis fra resten av kroppen - akkurat fordi det da er denne delen som står, som partialobjekt, i sentrum. Den blir, metaforisk talt, kuttet av fra resten av kroppen, idet den og dens adferd fokuseres separat. Eller med andre ord: Når det gjelder å få en ereksjon, så «gjelden» (det vil si: kastrerer) Malmborg seg selv på en symbolsk måte - akkurat ved å iscenesette phallocentrisme.

${ }^{67}$ Ved å beskrive bl.a. stemmen og blikket som partialobjekter supplerer Lacan i første omgang de partialobjektene som psykoanalytikerne Karl Abraham og Melanie Klein hadde, med utgangspunkt i Sigmund Freuds psykoanalytisk teori, definert tidligere (jf. Lacan, Jacques. Ecrits. Paris: Seuil, 1966). Senere beskriver han akkurat disse partialobjektene som manifestasjoner av det ovennevnte objet petit a (Jf. Lacan, Jacques. Le Séminaire. Livre XI. Les quatre concepts fondamentaux de la psychanalyse, 1964. Paris: Seuil. 1964).

${ }_{68}$ Både Dolar og Žižek fokusserer på stemmen og blikket som «the two paramount embodiments of the objet petit a» (Dolar, Mladen. A Voice and Nothing More. Cambridge, MA: MIT Press, 2006, 39; jf. også avsnitt II.2.1, «Blick und Stimme als Objekte», i Žižek, Slavoj. Liebe Dein Symptom wie Dich selbst. Jacques Lacans Psychoanalyse und die Medien. Berlin: Merve, 1991, 58-63). Stemmen står særlig i sentrum hos Dolar, som «voice without a body» (Dolar. A Voice and Nothing More, 40). Hos Žižek er stemmen ett av eksemplene på de kroppsløse organene som han beskriver i sin bok av samme navn (Jf. Žižek, Slavoj. Körperlose Organe. Bausteine für eine Begegnung zwischen Delenze und Lacan. Frankfurt am Main: Suhrkamp, 2005). Begrepet «kroppsløst organ» er i denne boken, i forhold og kontrast til Gilles Deleuzes og Félix Guattaris omvendte begrep «organløs kropp» (jf. Deleuze, Gilles og Félix Guattari. Capitalisme et schizophrénie. L'anti CEdipe. Paris: Les Editions de Minuit, 1972), samtidig den viktigste av de byggeklossene (Bausteine) for møtet mellom Deleuze og Lacan som nevnes i bokens undertittel.

${ }^{69}$ Malmborg, b o ne r. 
Kjønnsorganet blir i ereksjonsoppgavenen så å si oppgitt og gitt opp som den integrale bestanddelen av det mannlige subjektet. Den er i denne situasjonen, slik som stemmen sier det om seg selv, ikke et medium som uttrykker subjektivitet, men heller noe som er fjern, eller har blitt fjernet, fra subjektet. Selv om «the erection is pure Stanislavsky», som Malmborg har sagt ${ }^{70}$, kommer den egentlige årsaken for at det skal skje noe med kjønnsorganet ikke innenfra subjektet, men utenfra, som en pålagt oppgave. Og selv når oppgaven gjennomføres for andre gang, da med bistand fra en viagrapille som virker i kroppen, må denne pillen tilføres utenfra først. Både oppgaven og det å ta viagra pålegger Malmborg seg selvfølgelig selv. Men idet han gjør det til et prinsipp for iscenesettelsen, gir eller delegerer han agency til en ramme som er ytre i forhold til han - en symbolsk orden, i Lacans forstand, som han underkaster seg som «sub-jekt».

På denne måten utstilles samtidig akkurat det som, med Sigmund Freuds begrep, kan kalles for den super-ego-befalingen eller over-jeg-ordren som vanligvis gjelder skuespillere. At Malmborg utfører hver av sine oppgaver to ganger - først uten og så med hjelpemidler ${ }^{71}$ - kan ikke bare ses som en demonstrasjon av forskjellige skuespilltekniske måter å produsere følelsesuttrykk på. Det kan selvfølgelig tolkes som referanse til opplysningstidens skuespillteoretiske skille mellom den «varme» og den «kalde» skuespilleren ${ }^{72}$, og likeså i forhold til de to veiene til rollen - innenfra og utenfra som Konstantin S. Stanislavskij beskriver. ${ }^{73}$ Men det dreier seg ikke bare om å vise at følelsesuttrykket kommer på den ene siden innenfra, når oppgavene utføres uten hjelpemidler, og på den andre siden utenfra, når hjelpemidlene brukes (bortsett fra at det er uansett verken i det ene eller i det andre tilfellet mulig å si at de tilsvarende uttrykkene kommer enten bare innenfra eller bare utenfra). Det egentlige poenget er at Malmborg viser - idet han underkaster seg i hvert tilfelle en ytre ramme som han har delegert agency til - at begge måter å produsere følelsesuttrykk på er i grunn beordret utenfra. Nærmere bestemt viser han at det å produsere følelsesuttrykk er generelt sett en reaksjon på ytre impulser - impulser som treffer skuespilleren vanligvis i form av de forventningene som preger den stereotypiske oppfatningen om hva hens oppgave var. Og slik som disse impulsene kan kalles for super-ego-befaling eller over-jeg-ordre, så kan skuespillerens vanlige reaksjon på dem kalles for en form for å adlyde denne ordren. Med andre ord: Det som skuespillere vanligvis underkaster seg er imperativet å framstille noe tilsynelatende indre, å uttrykke og vise følelser (uansett hvordan de tilsvarende uttrykkene produseres), å være på en særlig intensiv måte tilstede, altså å fylle et egentlig tomt sentrum (både scenens sentrum og subjektets sentrum) med kropp, stemme og tale. Kort sagt: De adlyder over-jeg-ordren å fono- og fallogosentrere seg (som gjelder, fordi hele prinsippet er fallogosentristisk organisert, også for kvinnelige skuespillere). Malmborg derimot - idet han i ovennevnte symbolske forstand gjelder seg selv - snur dette

\footnotetext{
${ }^{70}$ Personlig kommunikasjon i en samtale med Malmborg på 02.03.2016, etter forestillingen av b o n e $r$ ved Oslo Internasjonale Teaterfestival. Utsagnet ble også del av tittelen til mitt foredrag "'The erection is pure Stanislavsky' - or: The 'as if in contemporary performing arts», presentert 06.03.2016 på festivalens seminar Om utoverrollen/Seminar about the role of the performer.

${ }^{71}$ Oppgaven med å finne på nye kunstneriske prosjekter skiller seg i dette henseende som sagt fra de tre andre oppgavene.

${ }^{72}$ Jf. særlig Saint-Albine, Pierre Rémond de. Le comédien. Paris: Desaint et Saillant, 1747; samt Riccoboni, François. L'Art du théatre. Paris: C.F. Simon fils, 1750; samt Diderot, Denis. Paradoxe sur le comédien. Paris: A. Sautelet, 1830.

${ }^{73}$ Jf. Stanislawski, Konstantin S. Die Arbeit des Schauspielers an der Rolle. Fragment eines Buchs. Berlin: Henschel, 1955, 67. For en utførlig drøfting av b o n e $r$ i forhold til skuespillteorier fra opplysnings- til samtiden se Eiermann, «Wenn ich möchte, dass Schauspielstudierende nachdenklich werden, geb’ ich ihnen einen Text von Heiner Goebbels».
} 
prinsippet på hodet. Hans kjønnsorgan reises ikke som den sentrale søylen som tilsynelatende støtter subjektets substans og tilstedeværelse innenfra. I stedet reises den på grunn av noe som er pålagt utenfra, altså oppgaven. Den står i sentrum, men som ensomt kroppsløst organ. Og Malmborgs kropp, selv om den ikke er fraværende, er ikke tilstede - i hvert fall ikke som kropp av et suverént og talende subjekt. Heller er denne kroppen, som tier stille så lenge oppgaven varer, et «sub-jekt» av den ytre rammen som Malmborg har delegert agency til.

I denne sammenhengen kan Malmborgs partielle nakenhet (og likeså Ingvartsens nakenhet i 69 positions) godt beskrives i forhold til det følgende Žižek-sitatet: «[]n today’s era of permissiveness, [...] performance and other artists are under pressure to stage the most intimate private fantasies in all their desublimated nakedness.») ${ }^{74}$ Både Malmborgs og Ingvartsens nakenhet er nemlig akkurat det motsatte til denne desublimerte nakenheten. Verken Malmorg eller Ingvartsen adlyder med deres nakenhet den permissive over-jeg-ordren som krever blottleggelsen av det mest intime og private. Tvert imot er det denne over-jeg-ordren selv, som Malmborgs og Ingvartsens nakenhet i stedet for å skjule den bak det den fordrer - blottlegger. ${ }^{75}$

På denne bakgrunnen, og særlig fordi ereksjonsoppgavens gjennomføring ikke alltid lykkes i samme grad, kan det avsluttende blikket på $b$ o n e $r$ nå, til sist, også bestå i å se denne oppgaven i sammenheng med ett av Žižeks ytterligere teoretiske perspektiver: At det å få en ereksjon viser seg i denne oppgavens gjennomføring å ikke være helt mulig å styre av det mannlige subjektet, selv ved bruk av viagra, tilsvarer Žižeks refleksjon over ereksjonens generelle ukontrollerbarhet. Nærmere bestemt: Den tittelgivende ereksjonen demonstrerer akkurat denne ukontrollerbarheten. Idet den viser seg som upålitelig, eksemplifiseres - som inversjon - det som Žižek beskriver med henblikk på uvilkårlige ereksjoner: at det mannlige kjønnsorganet, i motsetning til de fleste andre kroppsdelene, «escapes in principle man's free will» (altså det mannlige subjektets «willpower», som Malmborg snakker om) og er derfor «the point at which man's own body takes revenge on him for his false pride.» ${ }^{76}$

Som beskrivelsen av b o n e r har vist, gjør Malmborg altså på helt konkrete måter teater med teori. Sistnevnte fungerer både som inspirasjons- og impulsgiver samt som materiale $i$ hans arbeider. Dette betyr absolutt ikke at disse arbeidene derfor kun er forståelige for tilskuere som kjenner til de tilsvarende teoriene. Tvert imot er disse teoriene noe som setter scenekunstneriske utviklingsprosesser i gang, er del av disse og iscenesettes på måter som - ikke minst på grunn av en særlig humor - åpner for estetiske erfaringer som er uavhengig av en kjennskap til teoriene. Samtidig settes teoretiske refleksjonsprosesser i gang, fordi stereotypiske oppfatninger settes på spill scenisk. De oversetter, så å si, teori i et scenisk spill, som tilskuerne kan spille med i, selv om de ikke kjenner til oversettelsens «originalspråk». Det som riktignok er avgjørende i første rekke,

\footnotetext{
74 Žižek, Slavoj. The Parallax View. Cambridge, MA: MIT Press, 2006, 311.

${ }^{75}$ Det særlige poenget med $b$ o n e $r$ er i denne sammenhengen at arbeidet - ved å koble referansen til Derridas phallogocentrisme-kritikk sammen med referansen til Dolars og Žižeks beskrivelse av stemmen som kroppsløst organ - faktisk forbinder to forskjellige kritiske perspektiver på tilstedeværelsesimperativet med hverandre. For mens stemmen står og kritiseres hos Derrida for det som gir subjektet substans og bekrefter dets (illusoriske) tilstedeværelse, har stemmen som objekt i Dolars og Žižeks (og Lacans) forstand nettopp potensialet å grunnleggende forusikre og sette spørsmålstegn ved subjektets helhets- og tilstedeværelsesillusjon (jf. Žižek. Liebe Dein Symptom wie Dich selbst, 59-60; samt Dolar. A Voice and Notbing More, 42).

76 Žižek, Slavoj. The Sublime Object of Ideology. London, New York: Verso, 1989, 223.
} 
med henblikk på alle de eksemplene som er drøftet i denne artikkelen, er at de viser teatervitenskapens relevans for scenekunst. De viser, for å komme tilbake til utgangspunktet, at teatervitenskap består ikke bare i forskning på scenekunst, men at den er - på mangfoldige måter - knyttet til både forskning og kunstnerisk utviklingsarbeid og har - som vitenskapelig diskurs en performativ kraft i forhold til scenekunstneriske prosesser. 


\section{Bibliografi}

Aagaard Petersen, Jesper og Tone Pernille Østern. «Kunstskaping eller kunstnerisk utviklingsarbeid?». Scenekunst.no. 24.10.2017. http://www.scenekunst.no/sak/kunstskapingeller-kunstnerisk-utviklingsarbeid/

Arntzen, Knut Ove. «Mye står på spill for teatervitenskaps-faget i Bergen.» Bergens Tidende. 30.11.2017.

Austin, John Langshaw. How to do Things with Words. London, Oxford: Clarendon, 1975.

Bjørneboe, Therese. «Hvem er de?». Norsk Shakespeare- og Teatertidsskrift, nr. 2 (2018), Bonus til nettutgaven. http://shakespearetidsskrift.no/2018/08/hvem-er-de

Borgdorff, Henk. The Debate on Research in the Arts, Sensuous Knowledge no 2. Bergen: Kunsthøgskoeln I Bergen, 2006.

Deleuze, Gilles og Félix Guattari. Capitalisme et schizophrénie. L'anti CEdipe. Paris: Les Editions de Minuit, 1972.

Derrida, Jacques. Margins of Philosophy. Chicago: The University of Chicago Press, 1982.

Diderot, Denis. Paradoxe sur le comédien. Paris: A. Sautelet, 1830.

Dolar, Mladen. A Voice and Nothing More. Cambridge, MA: MIT Press, 2006.

Eiermann, André. «Wenn ich möchte, dass Schauspielstudierende nachdenklich werden, geb’ ich ihnen einen Text von Heiner Goebbels». I Landschaft mit entfernten Verwandten - Festschrift für Heiner Goebbels, redigert av Lorenz Aggermann, Eva Holling, Philipp Schulte, Bernhard Siebert, Gerald Siegmund og Katharina Stephan. 129-140. Berlin: Neofelis, 2018.

Eiermann, André. «I HATE THEATRE - IT’S JUST ILLUSION. Eine Praktik des Scheins als kritische Praxis: Zur Ironisierung anti-illusionistischer Topoi in Iggy und Maike Lond Malmborgs Performance 99 Words for Void». I Theater als Kritik: Theorie, Geschichte und Praktiken der Ent-Unterwerfung, redigert av Olivia Ebert, Eva Holling, Nikolaus MüllerSchöll, Philipp Schulte, Bernhard Siebert og Gerald Siegmund. 103-110. Bielefeld: Transcript, 2018.

Eiermann, André. «Behovet for dynamikk». Norsk Shakespeare- og Teatertidsskrift, nr. 2 (2018): 27-28.

Eiermann, André. «Pleasures to come». I herbst. Theorie zur Praxis, redigert av Martin Baasch, Flori Gugger, Andreas R. Peternell og Thomas Wolkinger. 101-103. Graz: steirischer herbst festival, 2015.

Eiermann, André. «A postspectacular perspective on 〈relational aesthetics» and audience participation». I Framing a Mirage. Communicating contemporary art and its values, redigert av Karoline Skuseth. 95-132. Bergen: BIT Teatergarasjen \& APAP - advancing performing arts project, 2015.

Eiermann, André, i intervju med Frøysnes, Valborg. «Hva kan teater være?». Norsk Shakespeare- og Teatertidsskrift, nr. 2 (2013): 6-10.

Eiermann, André. Postspektakuläres Theater - Die Alterität der Auffübrung und die Entgrenæung der Künste. Bielefeld: Transcript, 2009.

Eliassen, Knut Ove. «Arkivet og heterotopien». Kunstjournalen B-post, nr. 1 (2011). https://bpost.no/no/11/eliassen.html

Evans, Dylan. Wörterbuch der Lacanschen Psychoanalyse. Wien: Turia und Kant, 2002. 
Evert, Kerstin. «Die Theatermacher». I tan₹.de - Zeitgenössischer Tan₹ in Deutschland - Strukturen im $W$ andel - eine neue Wissenschaft. Arbeitsbuch 2005, redigert av Johannes Odenthal og Nina Peters. 164-166. Berlin: Theater der Zeit, 2005.

Foucault, Michel. L'archéologie du savoir. Paris: Gallimard, 1981

Gjervan, Ellen Karoline. «Komiske og historiske pantomimer rundt 1800 - I Europa, Norge og i norske teaterhistorien». Teatervitenskapelige studier 3 (2019): 17-26.

https://boap.uib.no/index.php/tvs/article/view/2925/2890

Ingvartsen, Mette. «Texts \& Interviews,» Mette Ingvartsen. 2020. https://www.metteingvartsen.net/texts-and-interviews/

Ingvartsen, Mette. «Biography,» Mette Ingvartsen. 2020. https://www.metteingvartsen.net/biography/

Ingvartsen, Mette. «69 positions,» Mette Ingvartsen. 2020. https://www.metteingvartsen.net/performance/69-positions/

Ingvartsen, Mette. EXPANDED CHOREOGRAPHY: Shifting the agency of movement in The Artificial Nature Project and 69 positions. Doktoravhandling. Stockholms Konstnärliga Högskola, Stockholm / Lunds Universitet, Malmö. 2016.

Lacan, Jacques. Le Séminaire. Livre XI. Les quatre concepts fondamentaux de la psychanalyse, 1964. Paris: Seuil. 1964.

Lacan, Jacques. Ecrits. Paris: Seuil, 1966.

Lacan, Jacques: Le Séminaire. Livre XX. Encore, 1972-1973. Paris: Seuil. 1975.

Latour, Bruno. «On Technical Mediation - Philosophy, Sociology, Genealogy». Common Knowledge 3, nr. 2 (1994): 29-64.

Latour, Bruno. Das Parlament der Dinge. Frankfurt am Main: Suhrkamp, 2010.

Le Witt, Sol. «Paragraphs on Conceptual Art». Artforum Vol. 5, nr. 10 (1967): 79-83.

Lond Malmborg, Iggy. «Towards Coprolalia». I Black Box teater-Publikasjon 3 / Publikasjon 3 , redigert av Elin Amundsen Grinaker og Anne-Cécile Sibué-Birkeland. 81-100. Oslo: Black Box teater, 2019.

Malmborg, Iggy. b o n e r. Forestilling. 12.11.2014.

Malterud, Nina, Torben Lai, Aslaug Nyrnes og Frode Thorsen. Forskning og utviklingsarbeid innen fagområdet kunst. 1995-2015: 20 år med kunstnerisk utviklingsarbeid. Oslo: UHR, 2015. https://www.uhr.no/ f/p1/i276102cc-6251-4224-81d0-2029453909f3/2015forskning og utviklingsarbeid innen fagomr det kunst.pdf

Marx, Karl. Das Kapital. Erster Band. Marx/Engels: Werke, Band 23. Berlin: Dietz, 1972, 97.

Mortensen, Jørn og Trond Lossius. «Ph.d. i kunstnerisk utviklingsarbeid - behov for en oppklaring». Scenekunst.no. 31.10.2017 http://www.scenekunst.no/sak/ph-d-i-kunstneriskutviklingsarbeid-behov-for-en-oppklaring/.

P.A.R.T.S. «School.» 2020. https://www.parts.be/about

P.A.R.T.S. «Program.» 2020. https://www.parts.be/programme-1

Pliny. Natural History, Volume IX, Books 33-35. Cambridge MA: Harvard University Press, 1952.

Riccoboni, François. L'Art du théâtre. Paris: C.F. Simon fils, 1750.

Saint-Albine, Pierre Rémond de. Le comédien. Paris: Desaint et Saillant, 1747. 


\section{EIERMANN}

Stanislawski, Konstantin S. Die Arbeit des Schauspielers an der Rolle. Fragment eines Bucbs. Berlin: Henschel, 1955.

Teaterhögskolan i Malmö. «Skådespelarprogrammet.» https://www.thm.lu.se/program-ochkurser/konstnarligt-kandidatprogram-i-skadespelarkonst-180-hp

Tornquist, Peter og Kjetil Solvik. «Ja, en kunstnerisk doktorgrad er veien å gå». Scenekunst.no. 30.10.2017. http://www.scenekunst.no/sak/ja-en-kunstnerisk-doktorgrad-er-veien-a-ga/

Ullerup Schmidt, Cecilie. «Carrying Voices - Producing Subjects on Stage in Reality». I who's there? - subjects on stage in reality, redigert av Miriam Frandsen og Cecilie Ullerup Schmidt. 12-23. København: The Danish National School of Theatre and Contemporary Dance Continuing Education, 2011.

Witzeling, Klaus. «NO MORE THEATRE. Eine Performance-Trilogie. Die Inszenierung in der Kritik». I Szene machen. Das Körber Studio Junge Regie, redigert av Nikolaus Besch, Susanne Kutz og Dirk Wegner. 30-32. Hamburg: edition Körber Stiftung, 2004.

Žižek, Slavoj. Liebe Dein Symptom wie Dich selbst. Jacques Lacans Psychoanalyse und die Medien. Berlin: Merve, 1991.

Žižek, Slavoj. The Parallax View. Cambridge, MA: MIT Press, 2006, 311.

Žižek, Slavoj. Körperlose Organe. Bausteine für eine Begegnung zwischen Deleuze und Lacan. Frankfurt am Main: Suhrkamp, 2005.

Žižek, Slavoj. The Sublime Object of Ideology. London, New York: Verso, 1989, 223. 